\title{
Worker Training in a Restructuring Economy: Evidence from the Russian Transition
}

\author{
By: Mark C. Berger, John S. Earle and Klara Z. Sabirianova
}

Working Paper Number 331

August 2000 


\title{
Worker Training in a Restructuring Economy: Evidence from the Russian Transition*
}

\author{
Mark C. Berger \\ Department of Economics and Center for Business and Economic Research, \\ University of Kentucky \\ John S. Earle \\ SITE, Stockholm School of Economics \\ Central European University \\ Stanford University \\ Klara Z. Sabirianova \\ William Davidson Institute, University of Michigan \\ Urals State University
}

August 21, 2000

* We acknowledge the helpful comments of Barry Ickes, Rostislav Kapelyushnikov, and participants at sessions at the annual meetings of the American Economic Association in Boston, MA on January 8, 2000 and the European Society of Population Economics in Bonn, Germany on June 15, 2000. 


\section{Abstract \\ Worker Training in a Restructuring Economy: Evidence from the Russian Transition}

We use 1994-1998 data from the Russian Longitudinal Monitoring Survey (RLMS) to measure the incidence and determinants of several types of worker training and to estimate the effects of training on workers' interindustry, interfirm, and occupational mobility, their labor force transitions, and their wage growth in Russia compared to the U.S. We hypothesize that the shock of economic liberalization in Russia may raise the benefits of training, particularly retraining for new jobs, but uncertainty concerning the revaluation of skills may raise the costs, with an overall ambiguous effect on the amount of training undertaken. The RLMS indicates a lower rate of formal training than studies have found for the U.S., suggesting that the second effect dominates. Previous schooling is estimated to affect the probability of training positively, but the relationship is much stronger for additional training in the same field than for retraining for new fields, consistent with the hypothesis that schooling and training are complementary but become more substitutable in a restructuring environment. Foreign ownership of the firm also positively affects the probability of undertaking training, providing evidence of active restructuring by foreigner investors. Additional training in workers' current fields is estimated to reduce mobility and earnings, suggesting inertial programs from the pre-transition era. Retraining in new fields increases all types of worker mobility and has higher returns than those typically observed for training in the U.S., but it also raises the variance of earnings and the probability of unemployment, consistent with a search view of such retraining. Given the large returns to retraining, the efforts of Russian workers to learn new skills may increase as uncertainty is resolved and restructuring proceeds.

Keywords: training, retraining, on-the-job training, mobility, labor market, transition, Russia 


\section{Introduction}

Worker training appears to play a central role in economic restructuring. When rapid structural change in technology or markets alter the relative value of various skills, training and retraining may be beneficial in facilitating the reallocation of labor to higher-valued uses. Despite the presence of such structural change in most modern economies, however, there has been rather little research on the influence of restructuring on the extent and nature of private-sector training decisions. Compared to training activities over the worker and job life cycle, the focus of most prior research, is more training actually undertaken by workers and firms in the restructuring context? How does structural change affect the determinants of training, in particular the relationship with prior formal schooling? Finally, what are the labor market consequences of training - including employment, wages, and job mobility - in a restructuring environment?

In this paper, we investigate these questions drawing upon the example of Russia, an economy undergoing vast structural changes in the 1990s. As in other transition economies, the socialist legacy of inefficiency in enterprise functioning and the large shifts in the demand for various types of labor associated with the initial shocks of transition suggest that workers should acquire new skills to be able to work with new technologies and to meet the demands of a market economy. Our underlying premise is that the magnitude and suddenness of the shock to the valuation of various types of skills in Russia may provide some general lessons on the role of training in the process of economic restructuring. We also compare our results with the empirical findings concerning private-sector training in stable market economies such as the U.S.

We argue that the restructuring context may raise the benefits of training, but the effects on the amount, the determinants, and the productivity of training are 
ambiguous nevertheless. To start with, it is possible that the costs of training particularly those faced by firms and workers - may also increase. If the new structure of returns to skill types is initially unknown, or only partly observed, then risk-averse agents may be reluctant to undertake investments. Only gradually, as relative price movements settle down, and search and experimentation with skill acquisition of various types unfolds, will the new earnings structure be revealed. As Bartel and Sicherman (1998) argue with respect to the possible future obsolence of skills due to technological change in the United States, our claim is that uncertainty about the new returns, as well as their future evolution, may actually depress training activities. Furthermore, the uncertainty may be reflected in a high variance in the outcomes of training.

Related to the incentives to acquire training, the characteristics that tend to lead individuals to train may differ in the restructuring context. Research going back to Mincer (1962) has emphasized the complementarity between formal schooling and subsequent on-the-job training. The complementarity may be lower under structural change, however, as the attributes associated with higher benefits or lower costs of skill acquisition may also change. Bartel and Sicherman (1998) find that a higher rate of technological change in an industry tends to reduce the training gap between higher and lower educated workers, implying that schooling and training become more substitutable. A similar effect may be present under structural change, suggesting a compositional change in the types of workers who acquire training, but an ambiguous impact on training overall. The relationship of job tenure with training may also be affected by the restructuring context; while Bartel and Sicherman (1998) and Loewenstein and Spletzer (1999b) find a positive association in U.S. data, this effect may be reduced by the need for labor reallocation. 
The amount and productivity of training may also be affected by the possibility that training institutions and practices may be initially unresponsive to a new structure of returns. While it is frequently remarked that public educational systems display such unresponsiveness, private organizations may also have decision-making problems and poor incentive structures, for instance due to inadequate corporate governance, and they may tend to continue inertially with training programs inherited from the past. The skills taught in these programs may have much lower value than they did formerly, and the acquisition of these skills may tend to reduce rather than enhance worker mobility. This also suggests that such firm characteristics as size (which has been found by Lowenstein and Spletzer (1999b) and Veum (1995) to be positively associated with training) and ownership (reflecting corporate governance issues) may be important determinants of training in the restructuring context.

A final consideration in evaluating training under restructuring is the possibility of a second type of supply-side adjustment problem. When the magnitude of structural change is such that wholly new skills are in demand, then the extent of training may be inhibited by a lack of qualified trainers for those new fields. In sectors such as financial services, retail trade, and marketing, where there was a complete vacuum at the beginning of transition, for instance, there may be very little opportunity for workers to obtain training. A shortage of trainers in new fields may tend to reinforce the inertial tendency for existing institutions to continue training in old fields, even if it produces little return.

In applying these arguments to an empirical analysis of training in the Russian restructuring economy, we suggest that a crucial distinction, albeit not entirely unambiguous, concerns the difference between retraining - the acquisition of new skills that are useful for changing jobs and thus for promoting labor reallocation - on the one 
hand, and types of additional training that simply enhance existing skills, on the other. While other studies using Western data have considered various components of total training (e.g., Barron, Berger, and Black, 1997; Lillard and Tan, 1992; Loewenstein and Spletzer, 1997, 1999a, 1999b; Lynch, 1992; Lynch and Black, 1998; Parent, 1999; Veum, 1993, 1995, 1997), none have disaggregated total training into retraining in different fields and additional training in the same field. Throughout the paper, we investigate the utility of this distinction, examining both the determinants and the consequences of these two types of training.

We hypothesize that restructuring will increase retraining but it may reduce additional training, with an ambiguous overall effect due to the opposing effects of return and risk concerning the new earnings structure. Retraining in new skills tends to increase wages and several types of worker mobility, including across jobs, occupations, and industries, while raising the variance of outcomes due to the uncertainty of returns. Additional training in the same type of skills workers already possess, on the other hand, may tend to retard mobility and may produce low returns in the restructuring context; some of this additional training may be the product of Sovietera training institutions that have continued operating in the transition. We also hypothesize that the unexpected nature of the transition permits us to disentangle some of the usual problems of simultaneity in estimating the effects of schooling and job tenure on training in more stable market economies and thus to shed light, from a new angle, on the degree of complementarity or substitutability between formal education, prior informal on-the-job training (proxied by tenure) and the formal job training programs we are able to measure.

Our empirical analysis of these hypotheses employs a household panel data set, the Russian Longitudinal Monitoring Survey (RLMS), for the years 1994 to 1998. To 
focus on the implications of training for restructuring the existing labor force, as opposed to the somewhat different issues of educational reform and problems of new entrants, we restrict the sample to individuals who were employed in 1994. With respect to the determinants of training, our method is to relate the characteristics of workers and employers to the probability and amount of training between 1994 and 1998. When examining the consequences of training, we take the 1998 outcomes, or the difference between the 1994 and 1998 outcomes, as our dependent variables. As discussed above, we distinguish additional training (in the same field as an individual is employed) from retraining (in other fields); these measures based on retrospective questions on the 1998 survey pertaining to the previous three years.

The closest line of research for western economies to the question of the effect of restructuring on training activities is the work discussed above by Bartel and Sicherman (1998, 1999), who use NLSY data to examine technological change and the acquisition of training. They present evidence that production workers in industries with higher rates of technological change are more likely to receive formal company training and that the training gap between high and low educated workers narrows. We build on their work and that of others, but by contrast with their analysis of the impact of differences in steady-state rates of technological change, the economic transition in Russia and other former socialist countries presents a situation more like a one-time shock, which we believe may provide some general lessons on the role of training in the process of economic restructuring.

Concerning other issues addressed in our paper, a growing body of research has examined labor mobility in Western economies, but very few have explicitly examined the relationship between training and labor mobility. Parent (1999) uses NLSY data and finds that training provided by employers reduces interfirm mobility. Loewenstein 
and Spletzer (1997, 1999a) also find a negative relationship between training and mobility using NLSY data. However, they argue that the causation in part may go the other way. Employers belatedly find out which employees are less mobile and are more likely to invest in their training. Veum (1997) also uses the NLSY and finds limited evidence that company training reduces turnover. Felstead, Green, Mayhew, and Pack (1999), using British survey data, find that training has little if any impact on mobility.

There is no evidence on the effects of training using direct measures of training for the transition economies, aside from research on the impact of government training and other active labor market programs for reemployment of the unemployed (e.g., O’Leary (1997), Earle and Pauna (1998), O’Leary, Kolodziejczyk, and Lazar (1998), Kluve et al (1999), Terrell and Sorm (1999), Lubyova and van Ours (1999), and Lechner (2000)) in Central Europe. While there have been studies of labor mobility in transition economies, none explicitly examines the relationship between training and mobility (Boeri and Flinn (1999), Orazem and Vodopivec (1997)). To our knowledge, there are no studies of transition economies that attempt an overall quantification of the incidence of formal training, nor that estimate the determinants and effects of training on standard labor market outcomes.

The rest of the paper proceeds as follows. In the next section, we develop our hypotheses concerning the likely role of training activities in a transition economy. Section 3 describes the data and Section 4 presents the results. A brief conclusion appears in Section 5. 


\section{Worker Training in Transition}

Russia in transition offers an unusual opportunity to examine the role of job training in a setting where there has been a large amount of structural change. The magnitudes of the changes dwarf what have been experienced in western economies due to plant closings, shifts in industrial and occupation demands, economic liberalization and the rise of market competition. Here we use this quasi-experiment to understand the incidence of various types of training and the effects of training on mobility and wages in the restructuring context.

We first consider the impact of restructuring on the amount of training. After decades of central planning, including strict controls on prices, wages, and all forms of economic activity, liberalization policies resulted in a drastic revaluation of activities and skills. If there is little uncertainty concerning the revaluation, then restructuring should raise the amount of training as workers shift their efforts to higher valued uses. But if uncertainty increases simultaneously, then risk-averse workers and firms may be less likely to undertake training. The situation has some similarity with Bartel and Sicherman's $(1998,1999)$ discussion of technological change, where the argument concerns industries with different rates of change, and uncertainty concerns the nature of future changes, that is the extent to which current skills may become obsolete. The transition was more akin to a one-time shock, particularly in countries such as Russia that adopted "big-bang" liberalizations, but the shock was so large that there was probably considerable uncertainty about the nature of the skill revaluation. Only gradually have workers and firms been able to learn, partly through experimentation and experience, where the new opportunities lie. Moreover, the severity of the recession, the lack of liquidity, and possibly a lack of qualified trainers might imply that formal programs are likely to be prohibitively expensive in the current 
environment. Thus, while it seems clear that the social value of training increases with the extent of resource misallocation and the necessity for restructuring, uncertainty and various constraints may result in less training than in a stable economy. These theoretical considerations imply an ambiguous relationship, and our measurement of training levels in Russia compared to the U.S. will reflect these two opposing effects.

An important distinction in analyzing training in the restructuring context concerns the relationship between a worker's existing skill set and the skills taught in training programs. Training under restructuring may be a response to the shifts in labor demand across occupations and industries; in this case it would represent a more radical departure from the worker's previous skills rather than simple enhancement of the skill sets workers had at the beginning of transition. Although the distinction between these two types of training (additional training for the same tasks as the current job versus retraining in other fields) has not been analyzed in the Western training literature, it would appear to be particularly important for a restructuring economy such that in Russia. On the other hand, additional training could still be sizable because of inertia in the activities of training institutions inherited from the Soviet economic system, which organized a large amount of formal training - much of it through apprenticeships and specialized sub-organizations within firms. In fact, during the Soviet era, virtually every worker went through a formal program to provide additional training in his or her current job every five to seven years. These leftover training programs from the Soviet era may be of limited value in the new situation, but they may be continued nonetheless due to poor organizational or individual incentives. Moreover, it seems likely that Soviet workers had a higher specificity of skills, both firm- and occupation-specific human capital, which might raise the costs of retraining to work in new firms or occupations. 
Indeed, we would argue that the degree to which training in Russia is dominated by retraining for new types of jobs may be taken as one indicator of the extent to which such obstacles have been overcome and genuine restructuring of the labor force is underway. Inertia may affect training decisions, so organizational characteristics such as corporate governance matter for training decisions. Inertia may be reflected in additional training in the same field in which an individual has worked. Such training reduces mobility and produces low and possibly negative returns.

Next, we turn to the determinants of training decisions: the relationship between the probability of training and the characteristics of workers and their employers. A first issue is the degree of complementarity or substitutability of formal schooling with subsequent training. Standard human capital theory going back to at least Mincer (1962) argues that different types of skill acquisition are complementary, and Veum (1995), Loewenstein and Spletzer (1999b), and Bartel and Sicherman (1998) have provided recent evidence in support of the positive schooling-training correlation. Empirical verification is hampered, however, by the possibility that schooling, subsequent skill acquisition, and career decisions are jointly determined. For instance, suppose that individuals have some unobserved "tolerance for change" that is associated with lower costs of formal schooling and training and also influences occupational choices (raising the attractiveness of fields in which change is more likely). Then the observation of a positive correlation between schooling and training may not reflect any complementarity of the two kinds of skill acquisition. In the transition context, however, the magnitude of the revaluation of skills was completely unforeseen, and educational choices by workers in our 1994 sample were made with little expectation of the shocks to come. Therefore, we can treat educational choices as 
exogenous with respect to subsequent training decisions, particularly where the latter involves retraining for new fields.

Our analysis of the relationship of schooling and training in the restructuring context builds on Bartel and Sicherman's (1998) analysis of the attenuation of this relationship in industries with more rapid rates of technological change; it even becomes negative at high levels of some technological change measures. The argument that schooling and training become more substitutable in an environment of rapid change may be extrapolated to the restructuring environment, implying that we should observe a lower level of complementarity between schooling and training, particularly when we analyze retraining for other fields.

Another important aspect of inherited human capital in the transition concerns previous work experience and job tenure as proxies for informal on-the-job training. Bartel and Sicherman (1998) among others, report positive relationships between both of these variables and the probability of training (defined as formal, companyorganized training). The positive association may be interpreted as evidence of complementarity among the types of human capital investment, but the interpretation is open to the objection that experience and more particularly job tenure may be endogenous, for reasons similar to those discussed in Loewenstein and Spletzer's (1998) analysis of training and mobility: firms tend to train stayers rather than movers. We can again exploit the unexpected nature of the transition to argue that previous job tenure is exogenous, thus providing a cleaner test of these relationships.

Some characteristics of firms, associated with the propensity to undertake restructuring, may also have an impact on training. Perhaps the most interesting hypothesis in the transition context concerns the relationship of firm ownership with the two types of training we have distinguished: additional training of workers in the same 
field and retraining in other fields. Here we would argue that corporate governance considerations suggest that firms that have been privatized to foreign investors or other controlling outsiders may be more likely to adopt new technologies and change job assignments, possibly requiring greater retraining of their workers. If retraining in a new field is taken as representing restructuring, while additional training in the same field is not (reflecting instead a lack of response to new incentives), then such firm characteristics may have different relationships with the different types of training.

With respect to the consequences of training, we investigate several types of worker mobility and wage growth. Concerning mobility, studies in the U.S. have found that firm-organized training tends to reduce inter-firm mobility (quit rates), and given that most training is firm-organized, the result may be generalized as an average result of training. Again, we argue that the restructuring context matters: if our conjecture that the return to switching firms, industries or occupations in Russia may be much greater than in the standard setting of a stable market economy, then training may lead to higher rather than lower quits from the firm, as well as increased mobility across industries and occupations. The positive impact of training on quits should be much more pronounced for retraining in new fields, and it could be zero or negative for additional training.

Finally, concerning the impact of training on wage growth, it strikes us that a restructuring economy should have many possibilities for productive, wage-increasing labor mobility, if the necessary new skills can be acquired. Since mobility in general, and skill acquisition in particular, are costly processes, the revalued occupations may pay significant rents for some time before labor supply adjustments are complete. If this reasoning is correct, then the return to training in Russia should be higher than in the U.S. On the other hand, if much Russian training results from the inertial activities 
of the old organizations set up to reproduce the skilled labor input for Soviet industry, then the return to training may be lower than in the U.S., since these sectors are dying in Russia. Furthermore, as we discussed above, job training may represent part of the process of search in the presence of uncertainty concerning the value of alternative opportunities. In this case, some experiments may be unsuccessful in the sense of leading to little or no wage growth, (although they may still contribute to learning about the nature of the human capital revaluation which has occurred). This reasoning implies that we may observe increased variation of earnings for workers undertaking training, particularly when it involves acquisition of skills in a different field than the worker's current job.

To summarize, three sets of empirical hypotheses emerge from our discussion in of the nature of training in a restructuring economy. First, we hypothesize that the total amount of training may be higher or lower, relative to the level in a stable market economy, because of the opposing effects of return and risk. But we have emphasized the importance of distinguishing retraining for new skills from additional training in the same field: quantities of each type may be taken as proxies for the amounts of restructuring and inertia, respectively. Second, concerning training determinants, we hypothesize that the impact of prior human capital on training is lower in a restructuring than in a stable economy, and lower for retraining than for additional training. Organizational characteristics associated with restructuring should be associated with training. Firms with concentrated outside owners, especially foreign investors, engage in more training. Third, concerning outcomes of training, we hypothesize that retraining increases job, industry, and occupational mobility while additional training in the same field reduces mobility. Returns to training overall may be higher or lower than in a stable economy; they are likely to be higher for retraining, 
lower and perhaps negative for additional training in the same field. Finally, retraining is risky: the returns are highly variable, and retraining may sometimes lead to unemployment.

We discuss the data used to address these hypotheses in the next section.

\section{Data}

The data for this study are drawn from the Russian Longitudinal Monitoring Survey (RLMS), based on the first national probability sample drawn in the Russian Federation. The RLMS data consist of two longitudinal surveys of more than ten thousand individuals during 1992-1993 (Rounds 1-4) and 1994-1996, 1998 (Rounds 58). We employ data from the $5^{\text {th }}$ Round in 1994 and the $8^{\text {th }}$ Round in 1998 . The size of the adult sample (individuals answering the adult questionnaire, typically individuals age 14 and over) in 1994 is 8,893 (4,896 employed), and in 1998 is 8,701 (4,250 employed). The number of adults in both the $1994 \& 1998$ rounds is 5,495 . The number of adults employed in both 1994 and 1998 is 2,419. The number of employed respondents in both years with non-missing values for the variables used in the training and mobility analyses is 2,333 . The number of respondents with non-missing values of the variables used in the wage growth analysis is 2,054 . We also use a somewhat larger sample made up of the 3,068 individuals working in 1994, regardless of their employment status in 1998.

The panel structure of the RLMS permits us to examine changes in job characteristics of respondents who did and did not receive training (e.g. occupation, industry, firm and wages). Below we describe the construction of the variables used in the empirical analysis. 


\section{Training Measures}

The training variables used in the analysis are constructed from a number of questions about participation in formal training programs that are asked in the RLMS. Although various types of informal skill acquisition, such as on-the-job learning, may represent quite important ways in which individuals enhance their skills and acquire new ones, we focus on formal training programs for measurement reasons. ${ }^{\square}$ We include any training organized by firms, government, private agencies, and by workers themselves. Our focus is on experienced workers to distinguish the job training and retraining issues that are central to restructuring from initial human capital acquisition decisions.

The first training measure is additional training in the same field, which is based on the 1998 RLMS question:

"During the last 3 years were you are you studying additional training courses in your current profession, field?"

The second is retraining, which is defined using the following 1998 RLMS question:

"During the last 2 years were you or are you studying courses where you studied some other profession, field, foreign language?"

These questions allow us, unlike previous studies, to examine the incidence of additional training and retraining, and to examine their effects on mobility and wage growth.

\footnotetext{
${ }^{1}$ Much of the evidence on the incidence of training in western economies pertains to formal training, largely because it is easier to measure (e.g. Lynch, 1992). Only a few surveys in the U.S. have attempted to measure informal training (e.g. the Employment Opportunity Pilot Project data, the Small Business Administration training survey data, the training supplements of the Current Population Surveys, the National Longitudinal Survey of the High School class of 1972, and National Longitudinal Survey of Youth). Loewenstein and Spletzer (1999b) discuss the difficulties of measuring informal training and the inconsistencies in the results across surveys. The evidence that does exist suggests that informal training has a high incidence rate, at least among new hires, in the U.S. economy. Using the 1992 Small Business Administration training survey, Barron, Berger, and Black (1997) find that $88.7 \%$ of new hires received informal training. However, since the work on the incidence of training is just beginning in Russia, it is
} 


\section{Worker Characteristics}

We use a number of worker characteristics in our analysis of training, employment, mobility, and wage growth. We include in our models basic demographic characteristics such as gender, age, and years of schooling. These demographic characteristics along with years of tenure on the current job are available in each wave of the RLMS. After examining the answers to a set of open-ended questions on the individual survey questionnaires, we created a set of occupational codes using the International Labor Organization ISCO four-digit system. These codes are free of inconsistencies over time that are apparent in the original RLMS coding. These new codes are used to create occupation control variables at the one-digit level and to create a measure of occupational mobility.

\section{Firm Characteristics}

Unfortunately, no information on industry of the firm employing the workerrespondent was included in the original, published data. Therefore, we created industry codes based on the Goskomstat 5-digit OKONH system after examining the answers to open-ended questions concerning the nature of the employer on each individual survey questionnaire. In the industrial sector, after identifying the enterprise, we assigned the industry code for that enterprise used by Goskomstat, as reported in the Registry of Industrial Firms. In the non-industrial sector, we assigned a code based on available information about the enterprise. These industry codes were used to create control variables (economic sectors of services, industry, and agriculture) and to create a measure of industrial mobility between 1994 and 1998.

In addition to industry, we created a set of dummy variables measuring ownership of the firm. For respondents working in industry we obtained ownership

natural to focus on formal training and to compare the results with those obtained for formal training in the United States. 
information from the Goskomstat Registry of Industrial Firms. We used the four Goskomstat categories of ownership: state, private, mixed (state-private), foreign. For respondents working in the non-industrial sector we followed two approaches. If there were several respondents working in the same firm, we measured ownership based on the majority opinion of the respondents or on the basis of a high-ranking individual within the firm. In this way, the ownership measure is consistent across all workers in the firm. If there was only one person working in the firm, we used that person's responses to questions about ownership.

The four categories of ownership (state, foreign, private, and mixed) are constructed using the following RLMS questions:

1. "Is the government the owner or co-owner of your enterprise?"

2. "Is your enterprise owned or co-owned by foreign firms or foreign individuals"

3. "Is your enterprise owned or co-owned by Russian private individuals or Russian private firms"

Foreign firms are those for which the answer to question 2 is "yes." State firms are those for which the answer to question 1 is "yes," the answer to question 2 is "no," and the answer to question 3 is "no." Firms designated as (domestic) private are those for which the answer to question 1 is "no," the answer to question 2 is "no," and the answer to question 3 is "yes." Mixed firms are those for which the answer to question 1 is "yes," the answer to question 2 is "no," and the answer to question 3 is "yes."

Firm size is measured using the response to the RLMS question:

"How many people work in your enterprise?"

Because there are many missing values for this variable, we also created a firm size missing variable that is used in the analysis. 


\section{Local Characteristics}

The share of workers employed in de novo firms is imputed for each RLMS district based on the RLMS question on the founding date of the enterprise. De novo firms are defined as firms founded between 1994 and 1998. This measure is used as a proxy for the local scale of job creation. The 1994 unemployment rate is taken from the regional yearbook and is determined using ILO methodology for each region in the Russian Federation. We expect to find a positive relationship between training and the share of workers employed in new firms. However, limited outside opportunities and a high unemployment rate probably reduce incentives to acquire additional training and retraining.

\section{Worker Mobility and Wage Growth}

Besides receipt of various types of training, the dependent variables in our analysis are worker mobility and wage growth. Worker mobility is measured in several ways. Using responses to the RLMS on the enterprise of the primary job, we construct a measure of interfirm mobility. Using the original RLMS survey responses, interfirm mobility is measured as a change in the enterprise of the primary job between 1994 and 1998. Occupational mobility is measured as a change in the newly created four-digit occupational code of the primary job between 1994 and 1998. Occupational mobility is further classified into interfirm occupational mobility, i.e., individuals who change occupations and firms, and intrafirm occupational mobility, i.e., individuals who change occupations but do not change firms. Industrial mobility is measured as a change in the five-digit industry code of the primary job between 1994 and 1998. These measures provide a comprehensive picture of the mobility of Russian workers.

We also measure mobility using the transition among employment states between 1994 and 1998. In particular, starting with a sample of those working in firms 
in 1994, we observe whether each individual in 1998 was still employed in a firm, was self-employed, was unemployed, or was out of the labor force. Among the employed in 1998, the self-employed are individuals whose primary job was individual economic activity or who does not work at a firm or enterprise with more than one worker. The unemployed are those who did not have a job at the time of the 1998 interview, who had searched for a job in the previous 30 days and who reported themselves available to accept an appropriate job in the previous week. Those out of the labor force did not have a job at the time of the 1998 interview and had not searched in the previous 30 days or had searched but were not ready to accept an appropriate job in the previous week.

Wage growth is the difference in log of contractual wages for the primary and secondary jobs between 1994 and 1998. We needed to compute the contractual wage for both 1994 and 1998 for consistency because it was not available in the earlier RLMS rounds (1994-1996). Earlier RLMS questionnaires only asked actual earnings in previous month. Actual paid earnings is not an appropriate measure of the contractual wage given that $40-60 \%$ of Russian workers have wage arrears. Actual paid earnings are lower than the contractual wage when people did not get their wages in previous month and they are higher than the contractual wage when accumulated wage debt is paid.

We have imputed the contractual wage in the following way. For workers with wage arrears, the contractual wage is the total wage debt on the primary and secondary jobs owed to the worker divided by the number of monthly wages owed. For workers without wage arrears the contractual wage is the actual monthly wage received last month from primary and secondary jobs. Wages are measured in nominal terms so we measure the log wage growth between 1994 and 1998 without controlling for inflation. 
However, since we have only one time period over which we are measuring wage growth, inflation between 1994 and 1998 is absorbed into the constant term of our log wage growth equation.

\section{Results}

In this section, we report our analysis of the training activities of Russian workers over the period 1994-1998 using the Russian Longitudinal Monitoring Survey data. Table 1 shows the incidence of formal training activities among Russian workers employed in 1994 and in both 1994 and 1998. Among those working in 1994, the training incidence rate between 1994 and 1998 is $11.93 \%$. For those working in both 1994 and 1998, 13.93\% received some form of training between 1994 and 1998. The majority of reported training is training received in the worker's current field. A smaller proportion of workers received retraining in other fields.

The RLMS also asks respondents about the duration of retraining and additional training in number of calendar days. We show in Table 1 the average number of calendar days over which training activities occurred. However, we choose to report the results using the incidence measures of training rather than the duration measures in the statistical models that follow. While we have also estimated our receipt of training, mobility, and wage growth models using the duration training measures and obtained qualitatively similar results to those reported below, we are concerned with the problem of measurement error inherent in the RLMS duration measures. The RLMS questions only ask about calendar days of training, not about the average hours of training per day. Bartel and Sicherman (1998) noticed a similar reliability problem with the pre1988 NLSY training duration measures. Barron, Berger, and Black (1997) find a greater correlation between firm and worker reports of formal training incidence than 
between firm and worker reports of the length of time it takes a worker to become fully trained in qualified, consistent with a greater potential measurement error problem with a length of time measure than with the incidence measure. ${ }^{2}$ Given this potential problem, we believe it is appropriate to focus on our analyses using the incidence measures of training.

How do the incidence estimates for Russia from the RLMS compare to the incidence of formal training activities in the United States? The U.S. Current Population Surveys (CPS) provide estimates of the incidence of training on both the previous and current job in 1983 and 1991. For 1983, Lillard and Tan (1992) report that $11.7 \%$ of men needed formal training on their previous job in order to obtain their current job, and $38.0 \%$ of men working at the time of the survey said that they had received training to improve their skills while on their current job. For 1991, Loewenstein and Spletzer (1999b) report a $44.1 \%$ incidence rate of formal training among 16-64 year old workers while on their current job. However, an important weakness of the CPS training data is that the reference period is the entire current job, which varies from worker to worker.

On the other hand, the National Longitudinal Survey of Youth (NLSY) provides estimates of formal training incidence over fixed time periods but for a limited age range of workers. The individuals in the NLSY were aged 14-21 in 1979 at the beginning of the panel. Veum (1993) reports on the training received by individuals in the NLSY aged 21-29 in 1986 over the period from 1986 to 1991 . He finds $38.0 \%$ received some type of training to help find a job, learn new job skills, or learn a new job between 1986 and 1991. Training categories in his analysis included business

\footnotetext{
${ }^{2}$ Veum (1995) also finds evidence consistent with this idea for company provided training. In regressions explaining wage levels and wage growth, the incidence of company provided training has a positive and significant effect on wage levels and wage growth, while hours of company provided
} 
school, vocational or technical institute, correspondence courses, formal company training, seminars outside of work, and other forms of training. Loewenstein and Spletzer (1999b) analyze the training data for the same cohort of individuals between 1993 and 1994. They find over that year $17.3 \%$ of workers had engaged in some type of formal training.

Thus, it appears that there is more formal training undertaken by workers in the United States than in Russia. However, comparisons are difficult because the NLSY samples are much younger than the RLMS samples (average age of 38.54 in 1994). In order to remove the age effects, we recalculated training incidence using the RLMS data for the same age ranges in the NLSY data. For 21-29 individuals in the RLMS, which matches the age range used by Veum (1993), the training incidence rate is 15.7\%. For the slightly older group of workers used by Loewenstein and Spletzer (1999b), the incidence rate is $13.9 \%$. These calculations make it apparent that the incidence rate of formal training in the RLMS data is substantially below that observed in the NLSY data for the same age groups. In fact, given the relatively small proportion of training activities in Russia devoted to retraining, the RLMS incidence rates most likely overstate the amount of useful training taking place.

Table 2 shows the mean characteristics of workers in 1994 in the full RLMS sample of workers and the mean characteristics by receipt of training in subsequent years, where the sample includes individuals working in 1994 and observed (and responding to the training questions) in 1998. An interesting difference in the types of firms for which individuals work by the type of training received is that individuals receiving training in the same field are more likely to be working for state-owned firms than are individuals receiving retraining. In contrast, individuals receiving training in problem with error in the measurement of hours of company provided training. 
other fields are more likely to be working for private domestic, foreign, or mixed firms than are individuals receiving training in the same field.

Table 3 provides probit estimates of the receipt of training as a function of several worker and firm characteristics. The first column shows the model explaining the receipt of any kind of training between 1994 and 1998. The next two columns show the models explaining the receipt of additional training and retraining. In the first column, we see that training falls with age and tenure, increases with schooling, is more likely to be undertaken by managers, professionals and technicians, is less likely to be undertaken by workers in industry and agriculture as opposed to services, is less likely to be undertaken by workers in domestic private firms, and is more likely to be undertaken by workers in large firms. Regions with a higher share of employed in de novo firms and lower unemployment rates tend to have higher incidence of training.

The results in models for the two individual types of training tell us what factors are driving the overall results for the receipt of training. For example, older individuals are likely to get less of both types of training. The variable measuring previous years of schooling has a much larger impact on additional training in the same field than on retraining, suggesting that the substitutability between schooling and training increases with the extent of restructuring. This is also consistent with Bartel and Sicherman's (1998) argument concerning the impact of technological change on the schoolingtraining relationship. Thus, the results here support the complementarity hypothesis overall, while providing some evidence that schooling may increase the ability to deal with change, thus substituting to some extent for training. In addition, service workers are more likely to invest in retraining while technicians are more likely to receive additional training. Firm size is a more important determinant for the receipt of additional training in the same field than it is for the retraining. 
We can compare our results on the determinants of the incidence of formal training in the RLMS with those for the United States reported by Loewenstein and Spletzer (1999b) using the 1993-94 NLSY data and by Veum (1995) using the 1990 NLSY data. Like the RLMS results, both Loewenstein and Spletzer (1999b) and Veum (1995) report that higher education levels are associated with higher probability of the receipt of training. Loewenstein and Spletzer (1999b) and Veum (1995) both find that larger firms are more likely to provide training (except for outside seminars), consistent with the RLMS results for the provision of training in the same field. The RLMS estimates suggest a flat tenure profile for the probability of receiving training (this is also the case when a quadratic tenure specification is employed). In contrast, Bartel and Sicherman (1998), Loewenstein and Spletzer (1999b), and Veum (1997) find fairly strong evidence that the probability of the receipt of formal training increases with tenure, although at a decreasing rate.

Turning to the effects of training, we first consider worker mobility of several types: across industries, firms, occupations, and labor force states, and within firms. Table 4 shows the proportion of all workers that experienced mobility between 1994 and 1998, along with mobility experiences of those workers that have received some form of training in that period. The mobility rates of those receiving retraining in other fields appear higher than the mobility rates of the typical worker. On the other hand, the mobility rates of those receiving training in the same field appear to be lower than those of the typical worker.

\footnotetext{
${ }^{3}$ While Veum (1995), using a linear specification, finds no relationship between the receipt of company provided training and tenure, Veum (1997), using a quadratic specification, finds that additional tenure increases the probability of the receipt of company provided training at decreasing rate, similar to Bartel and Sicherman (1998) and Loewenstein and Spletzer (1999b).
} 
Table 5 shows probit estimates explaining interindustry, interfirm mobility, and occupational mobility as a function of a number of worker and firm characteristics, including the receipt of training between 1994 and 1998. We focus on the results for the training variables. Additional training in the same field appears to reduce all types of mobility, while retraining appears to raise mobility. The results for additional training in the same field are consistent with those using NLSY data in the United States that the receipt of training is associated with lower mobility (e.g. Loewenstein and Spletzer 1997, 1999a; Parent, 1999). Retraining works in exactly the opposite direction, providing further support that the distinction between types of training is an important one. This type of training appears to facilitate worker mobility and is more likely to be the result of workers' adjustments to transition and restructuring than is additional training in the same field.

Finally, we note that the insignificant coefficients on years of schooling in each of the equations is slightly puzzling in light of the argument that schooling enhances the ability to deal with change. However, in some cases schooling may be more like an investment in occupation-specific skills. In these cases additional schooling may reduce the propensity to mobility, especially occupational mobility within and across firms, leading to the observation of insignificant effects in the mobility equations.

In Table 6, we estimate the effect of training on employment transitions between 1994 and 1998. We estimate a multinomial logit model in which the employed in 1994 either transition to self-employment, unemployment, out of the labor force, or remain employed in an enterprise in 1998 . $74.5 \%$ of the sample remains employed in an enterprise in 1998, $4.6 \%$ transitions to self-employment, $5.2 \%$ transitions to unemployment, and $15.7 \%$ transitions to out of the labor force in 1998. The reference category in Table 6 is remaining employed in an enterprise in 1998. This 
transition is a function of training and other observable firm and worker characteristics in 1994. We find that additional training in the same field reduces the probability of transiting from employment to self-employment, unemployment or out of the labor force relative to staying employed. Thus, additional training in the same field is associated with lower levels of mobility into any other employment state. In contrast, retraining only raises the probability of transiting to unemployment relative to remaining employed. While retraining may help mobility to a different industry or occupation, as we saw in Table 5, Table 6 also shows that there is some risk involved: it also raises the chances of being unemployed. Such unemployment may reflect training failures or it may represent productive search that is complementary with the new skills, but in either case the finding is consistent with our view of such retraining as involving search and experimentation in the presence of uncertainty.

Finally, in Table 7 we examine the relationship between training and wage growth. In the U.S., the typical finding is that training leads to increases in wage growth (e.g., Veum, 1995; Barron, Berger and Black, 1999; Loewenstein and Spletzer, 1999b), consistent with what one would expect from a standard human capital model. In Panel A, we show the average growth in nominal log wages between 1994 and 1998 for all workers and workers receiving the two different types of training. Across the entire sample, nominal log wages increase by 1.291 or $264 \%$ (calculated as $\exp (1.291)$ 1). At the same time, prices in Russia increased by $476 \%$ (CPI in December $1994=$ 43.234 (December 1995=100); CPI in December $1998=249.305$ ). So real wages of these workers declined substantially from 1994 to 1998 . The average wage growth of those obtaining retraining in another field is higher than the wage growth of the typical worker, while the average wage growth of workers receiving the additional training in the same field look similar to the wage growth of the typical worker. This provides 
some initial evidence that types of training associated with labor reallocation and acquisition of new skills may be more productive in a transition economy such as Russia's than training that merely enhances an existing skill set. Also note that the standard deviation of wages is higher for workers retraining than for additional training, consistent with our hypothesis that the revaluation of skills led to significant uncertainty about the returns to retraining of various types, thus that retraining involves a process of search.

In Panel B, Log wage growth between 1994 and 1998 is regressed on the log change in hours of work, a number of worker and firm characteristics observed in 1994, and whether workers have received training between 1994 and 1998. In the first column, we see that the dummy variable for either type of training in insignificantly related to wage growth. However, when the two separate types of training are included in the wage growth equation, a different pattern emerges. Consistent with theory, retraining raises wage growth. Additional training in the same field is associated with lower wage growth, even though as we saw in Table 6 that it was associated with more employment stability. These results suggest that the training most likely to be associated with restructuring, retraining in other fields, has the highest return. Training most likely to be coming from leftover programs from the pre-transition era, additional training in the same field, is less likely to be imparting skills valuable in a market economy and actually yields negative returns.

The returns obtained from retraining in other fields are substantially larger than those observed for training investments over similar periods in the United States. According to the estimates in Table 7, retraining increases log wages between 1994 and

\footnotetext{
${ }^{4}$ These results may be due in part to unobserved heterogeneity in the type of workers obtaining training. Because our dependent variable is wage growth rather than level, however, any fixed heterogeneity will be differenced out, leaving only heterogeneity that is correlated with the change in the value of human capital rather than the level of ability.
} 
1998 by .304 or $35.5 \%$ (calculated as $\exp (.304)-1) .5$ B Barron, Berger, and Black (1999) calculate elasticities of wage growth over a two year period with respect to training using the 1982 EOPP and 1992 SBA data. These elasticities are .028 and .020 respectively. While these seem fairly low compared to the Russian results, they cannot be directly compared because the training is measured in terms of hours rather than a dummy variable for the receipt of training. Better comparisons can be obtained using the NLSY results of Veum (1995) and Loewenstein and Spletzer (1999b). Using dummy variables for the reciept of training and controlling for a number of other characteristics, Veum (1995) finds that company provided formal training increases log wages between 1986 and 1990 by .0897 or $9.38 \%$ and that seminars outside of work increase log wages by .0848 or $8.85 \%$. Similarly, Loewenstein and Spletzer (1999b) find that after controlling for several characteristics, receipt of formal training increases $\log$ wages between 1993 and 1994 by .0328 or $3.33 \%$ across jobs and up to .0452 or $4.62 \%$ within jobs. These are much smaller estimated effects than those estimated for retraining in using the RLMS data between 1994 and 1998. The difference is even more impressive when we consider that the NLSY sample is much younger (e.g. ages 21-29 in 1986) with presumably steeper earnings profiles and possibly more intensive training activities than the older RLMS sample (average age $=38.47$ in 1994).

\section{Conclusion}

Most of the research on private-sector training decisions by workers and firms has ignored issues of structural change and demand shifts. Perhaps because Western

\footnotetext{
${ }^{5}$ One reader suggested that retraining may be more likely when an individual is faced with a larger negative shock, implying that the retraining variable is endogenous in the job mobility equations. However, this suggests that the coefficient on retraining should be biased downward in the wage growth equation. The fact that we find that retraining has a strong positive impact in the wage growth equation suggests that retraining is not only reflecting a negative shock.
} 
economies tend to be relatively stable, or perhaps because of economists' predilection for analyzing static equilibria, the focus has rather been on training patterns over the worker and job life-cycles. A notable exception is Bartel and Sicherman's (1998) analysis of the impact of technological change on the incidence of training and on the training gap between high and low-educated workers. In their analysis, technological change is treated as a continuous process, with a constant rate over time and varying only across industries. By contrast, the restructuring situation is more akin to a onetime shock of dramatic structural change and sudden shifts in the demand for different types of human capital.

This paper has made a first attempt to measure the causes and consequences of worker training in this restructuring environment. We have argued that transition economies in general, and Russia in particular, represent a fruitful setting to investigate this question, given the suddenness and magnitude of the shocks from liberalization and opening to the world economy.

We have hypothesized that the restructuring process, relative to the situation in a stable market economy, has ambiguous effects on the incidence of training. On the one hand, the need for labor reallocation would appear to promote training, particularly retraining of the "job-switching" type that provides new skills for new types of work. On the other hand, the increased uncertainty associated with the shift in the earnings structure suggests that workers and firms may be reluctant to undertake training investments. The possibility that formal schooling and training tend to be more substitutable in a restructuring context led us to conjecture that the correlation of the previous years of schooling and the training variables might be attenuated, similar to Bartel and Sicherman's (1998) argument concerning the impact of technological 
change. The role of firms in training their workers and the problems of corporate governance in the transition environment led us to hypothesize that training might be higher in privately owned companies, particularly those dominated by foreign investors. We also hypothesized that restructuring would tend to increase the covariance of training with mobility, as workers retrain for new types of work, and perhaps with wages, as the initial disequilibrium created by the transition shocks permits short-run rents to be gathered by the first movers to new fields.

Drawing upon household panel data for Russia, we have examined evidence concerning these hypotheses. Our findings suggest that that the incidence of formal training by Russian workers is below that observed for workers in the United States during roughly the same time period. We put forth the interpretation that uncertainty associated with the revaluation of skills may be outweighing the potential returns to training in a restructuring environment. Our analysis goes on to provide evidence for this interpretation in several ways. Retraining in other fields is estimated to have strongly positive effects on labor mobility and on wage growth, which supports our contention that such training has substantial potential returns, but it also raises wage variability and the probability of a transition to unemployment, implying there may be significant risks. The negative returns to additional training in the current field are consistent with the view that such training represents the inertia of the old system of training institutions. These training programs may be offering skills that might have been useful during the Soviet era but have ceased to be so in a restructuring economy.

The results thus suggest a fairly coherent picture of training in Russia. But they also provide some broader lessons for the analysis of training. First, we have demonstrated the importance of distinguishing retraining in new skills from additional training in the current field. Although the distinction is somewhat ambiguous and 
difficult to measure, our analysis shows substantial differences in behavior of the two types, both in the process determining the decision to undertake the training and in the consequences for mobility and earnings. Furthermore, understanding retraining requires an appreciation of the role of uncertainty and the tradeoff between risk and return, while additional training may be more explicable in terms of problems of corporate governance, bounded rationality, and costs of adjustment. The use of training appears to vary by type of firm, including size and industry, but we also show that certain types of owners - notably foreign investors - are more likely to engage in training their workers. Finally, our results also provide evidence that the substitutability of education and training increases in the restructuring context, as education has a much stronger effect on skill enhancement than on retraining for new jobs, while nonetheless confirming the education-training complementarity overall. Although these findings are based on our analysis of Russian data, they are suggestive of relationships that may hold in any economy restructuring in response to technological change or to shifts in preferences, resources or competition. 


\section{References}

Barron, John M., Mark C. Berger, and Dan A. Black, On-the-Job Training, Kalamazoo, MI: Upjohn Institute for Employment Research, 1997.

Barron, John M., Mark C. Berger, and Dan A. Black, "Do Workers Pay for On-the-Job Training," Journal of Human Resources 34(2), Spring 1999, 235-252.

Bartel, Ann P. and Nachum Sicherman, "Technological Change and the Skill Acquisition of Young Workers," Journal of Labor Economics 16(4), October 1998, 718-755.

Bartel, Ann P. and Nachum Sicherman, "Technological Change and Wages: An InterIndustry Analysis," Journal of Political Economy 107(2), April 1999, 285-325.

Boeri, Tito, and Christopher J. Flinn, "Returns to Mobility in the Transition to a Market Economy," Journal of Comparative Economics 27(1), March 1999, 4-32.

Earle, John S. and Catalin Pauna, "Long-Term Unemployment, Social Assistance and Labor Market Policies in Romania," Empirical Economics 23(1-2), 1998, 203-35.

Felstead, Alan, Francis Green, Ken Mayhew, and Alan Pack, "The Impact of Training on Labor Mobility," Centre for Labour Market Studies, University of Leicester, September 1999.

Kluve, Jochen, Hartmut Lehmann, and Christoph M. Schmidt, "Active Labor Market Policies in Poland: Human Capital Enhancement, Stigmatization, or Benefit Churning?" Journal of Comparative Economics 27(1), March 1999, 61-89.

Lechner, Michael, "An Evaluation of Public-Sector-Sponsored Continuous Vocational Training Programs in East Germany," Journal of Human Resources 35(2), Spring 2000, 347-375.

Lillard, Lee A. and Hong W. Tan, "Private Sector Training: Who Gets it and What are its Effects," Research in Labor Economics 13, 1992, 1-62.

Lubyova, Martina, and Jan C. van Ours, "Effects of Active Labor Market Programs on the Transition Rate from Unemployment into Regular Jobs in the Slovak Republic" Journal of Comparative Economics 27(1), March 1999, 90-112.

Lynch, Lisa M., "Private Sector Training and the Earnings of Young Workers," American Economic Review 82(1), March 1992, 299-312.

Lynch, Lisa M. and Sandra E. Black, "Beyond the Incidence of Employer-Provided Training," Industrial and Labor Relations Review 52(1), October 1998, 64-81.

Loewenstein, Mark A. and James R. Spletzer, "Delayed Formal On-the-Job Training," Industrial and Labor Relations Review 51(1), October 1997, 82-99. 
Loewenstein, Mark A. and James R. Spletzer, "General and Specific Training," Journal of Human Resources 34(4), Fall 1999a, 710-733.

Loewenstein, Mark A. and James R. Spletzer, "Formal and Informal Training:

Evidence from the NLSY," Research in Labor Economics, 18, 1999b, 403-438.

Mincer, Jacob, “On the Job Training: Costs, Returns, and Some Implications," Journal of Political Economy, 70, pt. 2, October 1962, 50-79.

O'Leary, Christopher J., "A Net Impact of Active Labour Programmes in Hungary," Economics of Transition 5(2), 1997, 453-484.

O’Leary, Christopher J., Piotr Kolodziejczyk, and Gyorgy Lazar, "The Net Impact of Labour Programmes in Hungary and Poland," International Labour Review 137(3), 1998, 321-346.

Orazem, Peter F. and Milan Vodopivec, "Value of Human Capital in Transition to Market: Evidence from Slovenia," European Economic Review 41(3-5), April 1997, 893-903.

Parent, Daniel, "Wages and Mobility: The Impact of Employer-Provided Training," Journal of Labor Economics 17(2), April 1999, 298-317.

Terrell, Katherine, and Vit Sorm, "Labor Market Policies and Unemployment in the Czech Republic" Journal of Comparative Economics 27(1), March 1999, 33-60.

Veum, Jonathan R., "Training Among Young Adults: Who, What Kind, and for How Long," Monthly Labor Review 116(8), August 1993, 27-32.

Veum, Jonathan R., "Sources of Training and Their Impact on Wages," Industrial and Labor Relations Review 48(4), July 1995, 812-826.

Veum, Jonathan R., "Training and Job Mobility among Young Workers in the United States," Journal of Population Economics 10(2), May 1997, 219-233. 
Table 1: Incidence of Training among Russian Workers between 1994 and 1998

\begin{tabular}{|l|c|c|}
\hline Incidence of Training (Percentage) & $\begin{array}{c}\text { Proportion of } \\
\text { Respondents } \\
\text { Employed in 1994 } \\
\text { Receiving Training }\end{array}$ & $\begin{array}{c}\text { Proportion of } \\
\text { Respondents } \\
\text { Employed in 1994 } \\
\text { and 1998 Receiving } \\
\text { Training }\end{array}$ \\
Any Type of Training & $11.93 \%$ & $13.93 \%$ \\
Additional Training (in the same field) & $9.88 \%$ & $12.00 \%$ \\
Retraining (in other fields) & $3.29 \%$ & $3.34 \%$ \\
N & {$[3,068]$} & {$[2,333]$} \\
\hline Average Duration of Training per Trainee (Days) & & 46.67 \\
Any Type of Training & 50.65 & {$[319]$} \\
N & {$[356]$} & 34.91 \\
Additional Training (in the same field) & 37.48 & {$[277]$} \\
N & {$[299]$} & 69.83 \\
Retraining (in other fields) & 72.02 & {$[76]$} \\
N & {$[96]$} & \\
\hline
\end{tabular}

Source: Authors' estimates from the Russian Longitudinal Monitoring Surveys. 
Table 2: 1994 Characteristics of Russian Workers, by Receipt of Training from 1994 to 1998

\begin{tabular}{|c|c|c|c|c|}
\hline & & $\begin{array}{c}\text { All Respondents } \\
\text { Employed in } 1994 \\
\text { and } 1998\end{array}$ & $\begin{array}{c}\text { Received } \\
\text { Additional } \\
\text { Training }\end{array}$ & $\begin{array}{c}\text { Received } \\
\text { Retraining }\end{array}$ \\
\hline 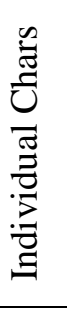 & $\begin{array}{l}\text { Female } \\
\text { Age (years) } \\
\text { Schooling (years) } \\
\text { Tenure (years) }\end{array}$ & $\begin{array}{c}0.536 \\
38.466 \\
(10.329) \\
11.932 \\
(2.484) \\
9.055 \\
(8.693)\end{array}$ & $\begin{array}{c}0.671 \\
37.675 \\
(10.108) \\
13.466 \\
(2.034) \\
8.657 \\
(8.354)\end{array}$ & $\begin{array}{c}0.667 \\
33.808 \\
(10.370) \\
12.801 \\
(2.218) \\
7.136 \\
(8.504)\end{array}$ \\
\hline .气 & $\begin{array}{l}\text { Managers and Professionals } \\
\text { Technicians } \\
\text { Clerks } \\
\text { Service Workers } \\
\text { Craft Workers } \\
\text { Operators and Assemblers } \\
\text { Unskilled Workers }\end{array}$ & $\begin{array}{l}0.207 \\
0.169 \\
0.074 \\
0.078 \\
0.182 \\
0.196 \\
0.094\end{array}$ & $\begin{array}{l}0.432 \\
0.293 \\
0.054 \\
0.036 \\
0.075 \\
0.086 \\
0.025\end{array}$ & $\begin{array}{l}0.308 \\
0.218 \\
0.077 \\
0.141 \\
0.077 \\
0.141 \\
0.038\end{array}$ \\
\hline 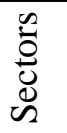 & $\begin{array}{l}\text { Industry } \\
\text { Agriculture } \\
\text { Services }\end{array}$ & $\begin{array}{l}0.290 \\
0.139 \\
0.571\end{array}$ & $\begin{array}{l}0.175 \\
0.032 \\
0.793\end{array}$ & $\begin{array}{l}0.321 \\
0.051 \\
0.628\end{array}$ \\
\hline อั & $\begin{array}{l}\text { State } \\
\text { Domestic Private } \\
\text { Mixed } \\
\text { Foreign }\end{array}$ & $\begin{array}{l}0.525 \\
0.143 \\
0.319 \\
0.013\end{array}$ & $\begin{array}{l}0.739 \\
0.061 \\
0.186 \\
0.014\end{array}$ & $\begin{array}{l}0.577 \\
0.115 \\
0.282 \\
0.026\end{array}$ \\
\hline$\stackrel{\tilde{N}}{\tilde{n}}$ & $\begin{array}{l}\text { Firm Size (,000 employed) } \\
\text { Firm Size Missing }\end{array}$ & $\begin{array}{c}2.166 \\
(15.707) \\
0.190\end{array}$ & $\begin{array}{c}4.820 \\
(27.832) \\
0.164\end{array}$ & $\begin{array}{c}1.563 \\
(5.363) \\
0.154\end{array}$ \\
\hline స్ర్ర & $\begin{array}{l}\text { Share of Employed in De } \\
\text { Novo Firms } \\
1994 \text { Unemployment Rate }\end{array}$ & $\begin{array}{c}0.158 \\
(0.081) \\
7.646 \\
(1.665) \\
\end{array}$ & $\begin{array}{c}0.168 \\
(0.079) \\
7.457 \\
(1.421) \\
\end{array}$ & $\begin{array}{c}0.185 \\
(0.066) \\
7.437 \\
(1.348) \\
\end{array}$ \\
\hline & $\mathrm{N}$ & 2,333 & 280 & 78 \\
\hline
\end{tabular}

Note: Standard deviations are in parentheses. Sample consists of respondents employed in 1994 and 1998.

Source: Authors' estimates from the Russian Longitudinal Monitoring Surveys. 
Table 3: Determinants of Receipt of Training 1994-1998, Probit Estimates

\begin{tabular}{|c|c|c|c|c|}
\hline & & $\begin{array}{l}\text { Receipt of any } \\
\text { Type of } \\
\text { Training }\end{array}$ & $\begin{array}{l}\text { Receipt of } \\
\text { Additional } \\
\text { Training }\end{array}$ & $\begin{array}{l}\text { Receipt of } \\
\text { Retraining }\end{array}$ \\
\hline 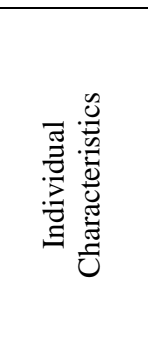 & $\begin{array}{l}\text { Female } \\
\text { Age (years) } \\
\text { Schooling (years) } \\
\text { Tenure (years) }\end{array}$ & $\begin{array}{l}0.011 \\
(0.784) \\
-0.002^{* * *} \\
(-3.009) \\
0.015^{* * *} \\
(3.901) \\
-0.001 \\
(-1.199)\end{array}$ & $\begin{array}{l}0.016 \\
(1.275) \\
-0.001 * * \\
(-2.127) \\
0.014 * * * \\
(3.962) \\
-0.001 \\
(-1.255)\end{array}$ & $\begin{array}{l}0.004 \\
(0.608) \\
-0.001 * * * \\
(-4.171) \\
0.002 \\
(1.280) \\
0.000 \\
(0.221)\end{array}$ \\
\hline 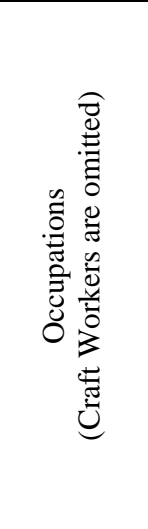 & $\begin{array}{l}\text { Managers and Professionals } \\
\text { Technicians } \\
\text { Clerks } \\
\text { Service Workers } \\
\text { Operators and Assemblers } \\
\text { Unskilled Workers }\end{array}$ & $\begin{array}{c}0.091 * * * \\
(3.374) \\
0.091 * * * \\
(3.650) \\
0.022 \\
(0.678) \\
-0.005 \\
(-0.149) \\
0.022 \\
(0.883) \\
-0.027 \\
(-0.752)\end{array}$ & $\begin{array}{c}0.069 * * * \\
(2.958) \\
0.068 * * * \\
(3.127) \\
0.008 \\
(0.292) \\
-0.040 \\
(-1.299) \\
0.010 \\
(0.429) \\
-0.040 \\
(-1.245)\end{array}$ & $\begin{array}{c}0.026 * * \\
(1.992) \\
0.020 \\
(1.626) \\
0.017 \\
(1.233) \\
0.033^{* *} \\
(2.521) \\
0.016 \\
(1.418) \\
0.009 \\
(0.526)\end{array}$ \\
\hline 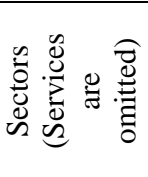 & $\begin{array}{l}\text { Industry } \\
\text { Agriculture }\end{array}$ & $\begin{array}{l}-0.030 * \\
(-1.693) \\
-0.095 * * * \\
(-3.528)\end{array}$ & $\begin{array}{l}-0.033 * * \\
(-2.110) \\
-0.086 * * * \\
(-3.435)\end{array}$ & $\begin{array}{l}0.014 * \\
(1.785) \\
-0.010 \\
(-0.788)\end{array}$ \\
\hline 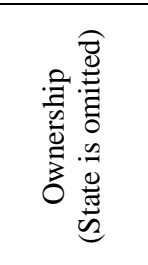 & $\begin{array}{l}\text { Domestic Private } \\
\text { Mixed } \\
\text { Foreign }\end{array}$ & $\begin{array}{l}-0.089 * * * \\
(-4.012) \\
-0.031 * \\
(-1.844) \\
-0.012 \\
(-0.223)\end{array}$ & $\begin{array}{l}-0.087 * * * \\
(-4.196) \\
-0.032 * * \\
(-2.231) \\
0.013 \\
(0.285)\end{array}$ & $\begin{array}{c}-0.015 \\
(-1.532) \\
-0.005 \\
(-0.565) \\
0.004 \\
(0.194)\end{array}$ \\
\hline$\stackrel{\tilde{N}}{\tilde{n}}$ & $\begin{array}{l}\text { Firm Size (,000 employed) } \\
\text { Firm Size Missing Dummy }\end{array}$ & $\begin{array}{l}0.001^{*} \\
(1.847 \\
-0.023 \\
(-1.389)\end{array}$ & $\begin{array}{l}0.001^{* *} \\
(1.976) \\
-0.010 \\
(-0.661)\end{array}$ & $\begin{array}{l}-0.000 \\
(-0.789) \\
-0.011 \\
(-1.470)\end{array}$ \\
\hline 厄్ّ & $\begin{array}{l}\text { Share of Employed in De Novo Firms } \\
1994 \text { Unemployment Rate }\end{array}$ & $\begin{array}{l}0.253 * * * \\
(3.341) \\
-0.009 * * \\
(-2.442)\end{array}$ & $\begin{array}{l}0.137 * * \\
(2.031) \\
-0.007 * * \\
(-2.081)\end{array}$ & $\begin{array}{l}0.120 * * * \\
(3.960) \\
-0.004 * \\
(-1.954)\end{array}$ \\
\hline & Intercept & $\begin{array}{l}-0.271 * * * \\
(-4.229)\end{array}$ & $\begin{array}{l}-0.252 * * * \\
(-4.436)\end{array}$ & $\begin{array}{l}-0.086 * * * \\
(-2.693)\end{array}$ \\
\hline & $\begin{array}{l}\text { LR chi2(19) } \\
\text { Pseudo } \mathrm{R}^{2}\end{array}$ & $\begin{array}{c}255.37 \\
0.138\end{array}$ & $\begin{array}{c}252.60 \\
0.151\end{array}$ & $\begin{array}{l}66.07 \\
0.087\end{array}$ \\
\hline
\end{tabular}

Note: $* * *$ - significant at the $1 \%$ level, $* *$ - significant at the $5 \%$ level; $*$-significant at the $10 \%$ level; t-statistics are in parentheses; t-statistics are defined with robust standard errors. Sample consists of respondents employed in 1994 and 1998. $\mathrm{N}=2,333$. The explanatory variables are measured in 1994. Coefficients show the marginal effect $\mathrm{dF} / \mathrm{dX}$. Source: Authors' estimates from the Russian Longitudinal Monitoring Surveys. 
Table 4: Mobility 1994-1998, by Receipt of Training

\begin{tabular}{|l|c|c|c|c|}
\hline & $\begin{array}{c}\text { All } \\
\text { Respondents } \\
\text { Employed in } \\
1994 \text { and } \\
1998\end{array}$ & $\begin{array}{c}\text { Received any } \\
\text { Type of } \\
\text { Training }\end{array}$ & $\begin{array}{c}\text { Received } \\
\text { Additional } \\
\text { Training }\end{array}$ & $\begin{array}{c}\text { Received } \\
\text { Retraining }\end{array}$ \\
\hline Interindustry Mobility & 0.244 & 0.203 & 0.168 & 0.372 \\
Interfirm Mobility & 0.266 & 0.222 & 0.186 & 0.397 \\
Occupational Mobility & 0.275 & 0.197 & 0.150 & 0.423 \\
$\quad$ Intrafirm Occupational Mobility & 0.127 & 0.091 & 0.070 & 0.191 \\
$\quad$ Interfirm Occupational Mobility & 0.148 & 0.106 & 0.080 & 0.232 \\
\hline $\mathrm{N}$ & 2,333 & 325 & 280 & 78 \\
\hline
\end{tabular}

Note: Sample consists of respondents employed in 1994 and 1998.

Source: Authors' estimates from the Russian Longitudinal Monitoring Surveys. 
Table 5: Training and Mobility 1994-1998, Probit Estimates

\begin{tabular}{|c|c|c|c|c|c|}
\hline & & $\begin{array}{c}\text { Inter-Industry } \\
\text { Mobility }\end{array}$ & $\begin{array}{c}\text { Interfirm } \\
\text { Mobility }\end{array}$ & $\begin{array}{c}\text { Occupational } \\
\text { Mobility }\end{array}$ & $\begin{array}{c}\text { Intrafirm } \\
\text { Mobility }\end{array}$ \\
\hline 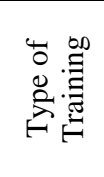 & $\begin{array}{l}\text { Additional Training } \\
\text { Retraining }\end{array}$ & $\begin{array}{l}-0.103 * * * \\
(-3.424) \\
0.130 * * * \\
(2.905)\end{array}$ & $\begin{array}{l}-0.112 * * * \\
(-3.607) \\
0.133 * * * \\
(2.820)\end{array}$ & $\begin{array}{l}-0.148 * * * \\
(-4.391) \\
0.185 * * * \\
(3.685)\end{array}$ & $\begin{array}{c}-0.039 \\
(-1.389) \\
0.091 * * \\
(2.080)\end{array}$ \\
\hline 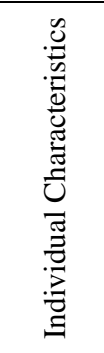 & $\begin{array}{l}\text { Female } \\
\text { Age (years) } \\
\text { Schooling (years) } \\
\text { Tenure (years) }\end{array}$ & $\begin{array}{l}-0.097 * * * \\
(-4.670) \\
-0.004 * * * \\
(-4.255) \\
0.001 \\
(0.223) \\
-0.009 * * * \\
(-6.747)\end{array}$ & $\begin{array}{l}-0.103 * * * \\
(-4.766) \\
-0.005 * * * \\
(-4.592) \\
0.002 \\
(0.457) \\
-0.009 * * * \\
(-6.810)\end{array}$ & $\begin{array}{l}-0.068 * * * \\
(-3.054) \\
-0.003 * * * \\
(-3.335) \\
0.007 \\
(1.212) \\
-0.006 * * * \\
(-4.311)\end{array}$ & $\begin{array}{c}-0.001 \\
(-0.080) \\
-0.001 \\
(-0.895) \\
0.002 \\
(0.374) \\
-0.001 \\
(-1.151)\end{array}$ \\
\hline 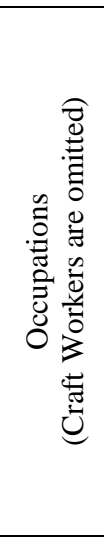 & $\begin{array}{l}\text { Managers and Professionals } \\
\text { Technicians } \\
\text { Clerks } \\
\text { Service Workers } \\
\text { Operators and Assemblers } \\
\text { Unskilled Workers }\end{array}$ & $\begin{array}{c}-0.059 * \\
(-1.643) \\
-0.040 \\
(-1.166) \\
-0.048 \\
(-1.120) \\
-0.102 * * \\
(-2.470) \\
-0.035 \\
(-1.247) \\
0.023 \\
(0.638)\end{array}$ & $\begin{array}{c}-0.047 \\
(-1.270) \\
-0.038 \\
(-1.077) \\
-0.039 \\
(-0.876) \\
-0.080 * \\
(-1.907) \\
-0.035 \\
(-1.193) \\
0.009 \\
(0.244)\end{array}$ & $\begin{array}{c}-0.112 * * * \\
(-2.872) \\
-0.072 * * \\
(-1.967) \\
-0.000 \\
(-0.007) \\
-0.045 \\
(-1.060) \\
-0.043 \\
(-1.451) \\
0.009 \\
(0.238)\end{array}$ & $\begin{array}{c}-0.082^{* *} \\
(-2.382) \\
-0.055^{*} \\
(-1.759) \\
-0.039 \\
(-1.082) \\
-0.023 \\
(-0.637) \\
-0.021 \\
(-0.833) \\
-0.024 \\
(-0.731)\end{array}$ \\
\hline 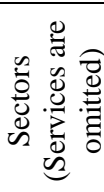 & $\begin{array}{l}\text { Industry } \\
\text { Agriculture }\end{array}$ & $\begin{array}{l}-0.029 \\
(-1.150) \\
-0.123 * * * \\
(-3.847)\end{array}$ & $\begin{array}{l}-0.045^{*} \\
(-1.722) \\
-0.145^{* * *} \\
(-4.304)\end{array}$ & $\begin{array}{l}0.029 \\
(1.127) \\
0.099 * * * \\
(3.139)\end{array}$ & $\begin{array}{l}0.009 \\
(0.365) \\
0.109 * * * \\
(4.403)\end{array}$ \\
\hline 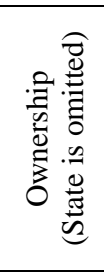 & $\begin{array}{l}\text { Domestic Private } \\
\text { Mixed } \\
\text { Foreign }\end{array}$ & $\begin{array}{c}0.123 * * * \\
(4.634) \\
0.044^{*} \\
(1.850) \\
0.108 \\
(1.539)\end{array}$ & $\begin{array}{l}0.149 * * * \\
(5.383) \\
0.060 * * \\
(2.392) \\
0.096 \\
(1.315)\end{array}$ & $\begin{array}{c}0.100 * * * \\
(3.535) \\
-0.003 \\
(-0.117) \\
0.073 \\
(0.923)\end{array}$ & $\begin{array}{c}0.004 \\
(0.135) \\
0.022 \\
(1.086) \\
0.036 \\
(0.502)\end{array}$ \\
\hline$\stackrel{\mathscr{N}}{2}$ & $\begin{array}{l}\text { Firm Size (,000 employed) } \\
\text { Firm Size Missing Dummy }\end{array}$ & $\begin{array}{c}-0.005 * * \\
(-2.022) \\
0.019 \\
(0.844)\end{array}$ & $\begin{array}{c}-0.006 * * \\
(-2.024) \\
0.045^{*} \\
(1.927)\end{array}$ & $\begin{array}{c}-0.002 \\
(-1.441) \\
0.018 \\
(0.769)\end{array}$ & $\begin{array}{c}-0.001 \\
(-0.917) \\
0.007 \\
(0.331)\end{array}$ \\
\hline $\begin{array}{l}\overline{\mathscr{J}} \\
\text { త్ }\end{array}$ & $\begin{array}{l}\text { Share of Employed in De } \\
\text { Novo Firms } \\
1994 \text { Unemployment Rate }\end{array}$ & $\begin{array}{l}0.279 * * \\
(2.586) \\
-0.003 \\
(-0.449)\end{array}$ & $\begin{array}{l}0.373 * * * \\
(3.346) \\
-0.004 \\
(-0.674)\end{array}$ & $\begin{array}{l}0.306^{* * *} \\
(2.631) \\
-0.006 \\
(-0.996)\end{array}$ & $\begin{array}{c}0.032 \\
(0.316) \\
-0.003 \\
(-0.683)\end{array}$ \\
\hline & $\begin{array}{l}\text { LR chi2(23) } \\
\text { Pseudo } \mathrm{R}^{2} \\
\mathrm{~N}\end{array}$ & $\begin{array}{c}268.52 \\
0.104 \\
2,333\end{array}$ & $\begin{array}{l}295.56 \\
0.112 \\
2,333\end{array}$ & $\begin{array}{c}197.84 \\
0.073 \\
2,333\end{array}$ & $\begin{array}{l}77.85 \\
0.058 \\
1,712\end{array}$ \\
\hline
\end{tabular}

Notes: $* * *$ - significant at the $1 \%$ level, ** - significant at the $5 \%$ level; *-significant at the $10 \%$ level; t-statistics are in parentheses and defined with robust standard errors. Sample consists of respondents employed in 1994 and 1998 (last column includes only those not changing firms from 1994-98). The explanatory variables except training are measured in 1994. Coefficients show the marginal effect $\mathrm{dF} / \mathrm{dX}$. Intercept is not shown.

Source: Authors' estimates from the Russian Longitudinal Monitoring Surveys. 
Table 6: Training and Employment Transitions 1994-1998, MNL Estimates

\begin{tabular}{|c|c|c|c|c|}
\hline & & $\begin{array}{l}\text { Transition to Self } \\
\text {-Employment }\end{array}$ & $\begin{array}{c}\text { Transition to } \\
\text { Unemployment }\end{array}$ & $\begin{array}{l}\text { Transition to Out- } \\
\text { of-Labor Force }\end{array}$ \\
\hline 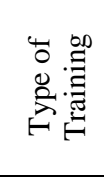 & $\begin{array}{l}\text { Additional Training } \\
\text { Retraining }\end{array}$ & $\begin{array}{c}-0.032 * * \\
(-1.988) \\
0.022 \\
(1.401)\end{array}$ & $\begin{array}{l}-0.018 \\
(-1.175) \\
0.042 * * * \\
(2.726)\end{array}$ & $\begin{array}{l}-0.199 * * * \\
(-4.678) \\
-0.024 \\
(-0.466)\end{array}$ \\
\hline 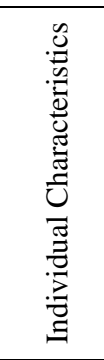 & $\begin{array}{l}\text { Female } \\
\text { Age (years) } \\
\text { Schooling (years) } \\
\text { Tenure (years) }\end{array}$ & $\begin{array}{l}-0.024 * * * \\
(-3.266) \\
-0.000 \\
(-1.252) \\
-0.001 \\
(-0.288) \\
-0.001 * \\
(-1.914)\end{array}$ & $\begin{array}{l}-0.003 \\
(-0.323) \\
-0.001 * * * \\
(-3.028) \\
-0.001 \\
(-0.633) \\
-0.001 \\
(-1.343)\end{array}$ & $\begin{array}{c}0.019 \\
(1.447) \\
0.007 * * * \\
(11.317) \\
-0.011 * * * \\
(-4.245) \\
0.000 \\
(0.456)\end{array}$ \\
\hline 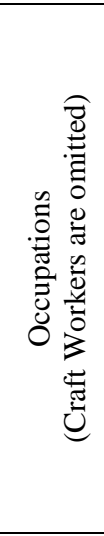 & $\begin{array}{l}\text { Managers and Professionals } \\
\text { Technicians } \\
\text { Clerks } \\
\text { Service Workers } \\
\text { Operators and Assemblers } \\
\text { Unskilled Workers }\end{array}$ & $\begin{array}{c}-0.005 \\
(-0.388) \\
-0.009 \\
(-0.711) \\
-0.016 \\
(-0.930) \\
-0.007 \\
(-0.548) \\
-0.012 \\
(-1.234) \\
-0.021 \\
(-1.529) \\
\end{array}$ & $\begin{array}{c}-0.006 \\
(-0.363) \\
0.005 \\
(0.374) \\
-0.016 \\
(-0.835) \\
0.005 \\
(0.312) \\
-0.016 \\
(-1.203) \\
0.022 \\
(1.597) \\
\end{array}$ & $\begin{array}{c}-0.029 \\
(-1.219) \\
0.016 \\
(0.790) \\
0.000 \\
(0.020) \\
0.014 \\
(0.619) \\
-0.035^{* *} \\
(-1.996) \\
0.016 \\
(0.795) \\
\end{array}$ \\
\hline 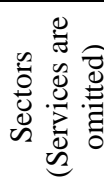 & $\begin{array}{l}\text { Industry } \\
\text { Agriculture }\end{array}$ & $\begin{array}{c}-0.012 \\
(-1.297) \\
-0.007 \\
(-0.570)\end{array}$ & $\begin{array}{c}0.005 \\
(0.465) \\
-0.016 \\
(-1.079)\end{array}$ & $\begin{array}{c}-0.018 \\
(-1.265) \\
0.021 \\
(1.370)\end{array}$ \\
\hline 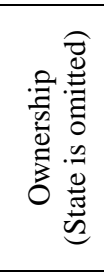 & $\begin{array}{l}\text { Domestic Private } \\
\text { Mixed } \\
\text { Foreign }\end{array}$ & $\begin{array}{l}0.035^{* * *} \\
(4.129) \\
-0.008 \\
(-0.744) \\
0.048^{* *} \\
(2.478)\end{array}$ & $\begin{array}{c}0.021 * \\
(1.862) \\
-0.006 \\
(-0.573) \\
0.036 \\
(1.323)\end{array}$ & $\begin{array}{c}0.024 \\
(1.486) \\
-0.000 \\
(-0.032) \\
-0.082 \\
(-1.164)\end{array}$ \\
\hline$\stackrel{\mathscr{N}}{2}$ & $\begin{array}{l}\text { Firm Size (,000 employed) } \\
\text { Firm Size Missing Dummy }\end{array}$ & $\begin{array}{l}-0.000 \\
(-0.034) \\
0.014 * * \\
(2.008)\end{array}$ & $\begin{array}{c}0.000 \\
(0.112) \\
0.003 \\
(0.359)\end{array}$ & $\begin{array}{c}-0.001 \\
(-0.854) \\
0.018 \\
(1.358)\end{array}$ \\
\hline ฮ్ & $\begin{array}{l}\text { Share of Employed in De Novo } \\
\text { Firms } \\
1994 \text { Unemployment Rate }\end{array}$ & $\begin{array}{l}-0.044 \\
(-1.090) \\
-0.003 \\
(-1.199)\end{array}$ & $\begin{array}{c}-0.037 \\
(-0.746) \\
0.004 * * \\
(2.321)\end{array}$ & $\begin{array}{l}-0.199 * * * \\
(-3.005) \\
0.012 * * * \\
(3.930)\end{array}$ \\
\hline & Intercept & $\begin{array}{c}-0.041 \\
(-1.258)\end{array}$ & $\begin{array}{l}-0.069^{*} \\
(-1.863)\end{array}$ & $\begin{array}{l}-0.349 * * * \\
(-6.955)\end{array}$ \\
\hline
\end{tabular}

Notes: $* * *$ - significant at the $1 \%$ level, $* *$ - significant at the $5 \%$ level; $*$-significant at the $10 \%$ level; $\mathrm{t}$-statistics are in parentheses and defined with robust standard errors. Sample consists of respondents employed in 1994. The explanatory variables except training are measured in 1994. Training is received between 1994 and 1998. Coefficients show the marginal effect dF/dX. The base category is employed in 1994 and 1998.

Source: Authors' estimates from the Russian Longitudinal Monitoring Surveys. 
Table 7: The Impact of Training on Wage Growth, 1994-1998

Panel A: Wage Growth 1994-1998, by Receipt of Training 1994-1998

\begin{tabular}{|l|c|c|c|c|}
\hline & $\begin{array}{c}\text { All } \\
\text { Respondents } \\
\text { Employed in } \\
\text { 1994 and 1998 }\end{array}$ & $\begin{array}{c}\text { Received any } \\
\text { Type of } \\
\text { Training }\end{array}$ & $\begin{array}{c}\text { Received } \\
\text { Additional } \\
\text { Training }\end{array}$ & $\begin{array}{c}\text { Received } \\
\text { Retraining }\end{array}$ \\
\hline $\begin{array}{l}\text { Nominal Log Wage Growth, 1994- } \\
1998\end{array}$ & 1.291 & 1.316 & 1.286 & 1.621 \\
N & $(1.001)$ & $(1.062)$ & $(1.047)$ & $(1.315)$ \\
\hline
\end{tabular}

Note: Standard deviations are in parentheses.

Panel B: Least Squares Estimates of Logarithmic Nominal Wage Growth, 1994-1998

\begin{tabular}{|c|c|c|}
\hline Independent Variables & (1) & (2) \\
\hline Any Type of Training & $\begin{array}{c}-0.062 \\
(-0.935)\end{array}$ & \\
\hline Additional Training & & $\begin{array}{l}-0.133 * \\
(-1.933)\end{array}$ \\
\hline Retraining & & $\begin{array}{l}0.304^{*} \\
(1.825)\end{array}$ \\
\hline Growth Rate of Hours of Work, 1994-98 & $\begin{array}{l}0.161 * * * \\
(4.019)\end{array}$ & $\begin{array}{l}0.159 * * * \\
(3.982)\end{array}$ \\
\hline Hours of Work Missing & $\begin{array}{c}0.056 \\
(0.867)\end{array}$ & $\begin{array}{c}0.054 \\
(0.843)\end{array}$ \\
\hline Female & $\begin{array}{l}-0.115^{* *} \\
(-2.129)\end{array}$ & $\begin{array}{l}-0.114 * * \\
(-2.108)\end{array}$ \\
\hline Age (years) & $\begin{array}{l}-0.006^{* * *} \\
(-2.609)\end{array}$ & $\begin{array}{l}-0.006^{* *} \\
(-2.533)\end{array}$ \\
\hline Schooling (years) & $\begin{array}{c}-0.009 \\
(-0.690)\end{array}$ & $\begin{array}{c}-0.010 \\
(-0.724)\end{array}$ \\
\hline Tenure (years) & $\begin{array}{l}-0.008 * * * \\
(-2.768)\end{array}$ & $\begin{array}{l}-0.008 * * * \\
(-2.773)\end{array}$ \\
\hline Occupation (craft workers are omitted) & & \\
\hline Managers and Professionals & $\begin{array}{c}0.112 \\
(1.225)\end{array}$ & $\begin{array}{c}0.119 \\
(1.293)\end{array}$ \\
\hline Technicians & $\begin{array}{l}0.187 * * \\
(2.349)\end{array}$ & $\begin{array}{l}0.192 * * \\
(2.418)\end{array}$ \\
\hline Clerks & $\begin{array}{c}0.030 \\
(0.311)\end{array}$ & $\begin{array}{c}0.028 \\
(0.284)\end{array}$ \\
\hline Service Workers & $\begin{array}{c}-0.004 \\
(-0.040)\end{array}$ & $\begin{array}{c}-0.020 \\
(-0.210)\end{array}$ \\
\hline Operators and Assemblers & $\begin{array}{c}-0.068 \\
(-0.904)\end{array}$ & $\begin{array}{c}-0.072 \\
(-0.958)\end{array}$ \\
\hline Unskilled Workers & $\begin{array}{c}-0.021 \\
(-0.234)\end{array}$ & $\begin{array}{c}-0.022 \\
(-0.243)\end{array}$ \\
\hline Intercept & $\begin{array}{l}1.719 * * * \\
(8.748)\end{array}$ & $\begin{array}{l}1.716^{* * * *} \\
8.724\end{array}$ \\
\hline $\begin{array}{l}\mathrm{N}=2,054 \\
\mathrm{R}^{2}\end{array}$ & $\begin{array}{c}\mathrm{F}(13,2040)=5.29 \\
0.033\end{array}$ & $\begin{array}{c}F(14,2039)=5.36 \\
0.037\end{array}$ \\
\hline
\end{tabular}

Notes: $* * *$ - significant at the $1 \%$ level, $* *$ - significant at the $5 \%$ level; *-significant at the $10 \%$ level; t-statistics are defined with robust standard errors. Standard deviations are in parentheses. Sample consists of employed in 1994 and 1998 (2,054 observations with complete wage data for 1994 and 1998). The explanatory variables besides growth rate in hours worked and training are measured in 1994.

Source: Authors' estimates from the Russian Longitudinal Monitoring Surveys. 


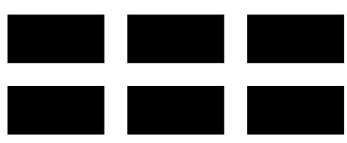

THE WILLIAM DAVIDSON INSTITUTE

AT THE UNIVERSITY OF MICHIGAN BUSINESSSCHOOL

\section{DAVIDSON INSTITUTE WORKING PAPER SERIES}

CURRENT AS OF 8/10/00

\begin{tabular}{|c|c|c|}
\hline Publication & Authors & Date of Paper \\
\hline $\begin{array}{l}\text { No. } 331 \text { Worker Training in a Restructuring } \\
\text { Economy: Evidence from the Russian } \\
\text { Transition }\end{array}$ & $\begin{array}{l}\text { Mark C. Berger, John S. Earle and Klara } \\
\text { Z. Sabirianova }\end{array}$ & August 2000 \\
\hline $\begin{array}{l}\text { No. 330 Economic Development in Palanpur } \\
\text { 1957-1993: A Sort of Growth }\end{array}$ & Peter Lanjouw & August 2000 \\
\hline $\begin{array}{l}\text { No. } 329 \text { Trust, Organizational Controls, } \\
\text { Knowledge Acquisition from the Foreign } \\
\text { Parents, and Performance in Vietnamese } \\
\text { International Joint Ventures }\end{array}$ & $\begin{array}{l}\text { Marjorie A. Lyles, Le Dang Doanh, and } \\
\text { Jeffrey Q. Barden }\end{array}$ & June 2000 \\
\hline $\begin{array}{l}\text { No. } 328 \text { Comparative Advertising in the } \\
\text { Global Marketplace: The Effects of Cultural } \\
\text { Orientation on Communication }\end{array}$ & $\begin{array}{l}\text { Zeynep Gürhan-Canli and Durairaj } \\
\text { Maheswaran }\end{array}$ & August 2000 \\
\hline $\begin{array}{l}\text { No. } 327 \text { Post Privatization Enterprise } \\
\text { Restructuring }\end{array}$ & Morris Bornstein & July 2000 \\
\hline No. 326 Who is Afraid of Political Instability? & Nauro F. Campos and Jeffrey B. Nugent & July 2000 \\
\hline $\begin{array}{l}\text { No. } 325 \text { Business Groups, the Financial } \\
\text { Market and Modernization }\end{array}$ & Raja Kali & June 2000 \\
\hline $\begin{array}{l}\text { No. } 324 \text { Restructuring with What Success? A } \\
\text { Case Study of Russian Firms }\end{array}$ & Susan Linz & July 2000 \\
\hline $\begin{array}{l}\text { No. } 323 \text { Priorities and Sequencing in } \\
\text { Privatization: Theory and Evidence from the } \\
\text { Czech Republic }\end{array}$ & $\begin{array}{l}\text { Nandini Gupta, John C. Ham and Jan } \\
\text { Svejnar }\end{array}$ & May 2000 \\
\hline $\begin{array}{l}\text { No. } 322 \text { Liquidity, Volatility, and Equity } \\
\text { Trading Costs Across Countries and Over } \\
\text { Time }\end{array}$ & $\begin{array}{l}\text { Ian Domowitz, Jack Glen and Ananth } \\
\text { Madhavan }\end{array}$ & March 2000 \\
\hline $\begin{array}{l}\text { No. } 321 \text { Equilibrium Wage Arrears: } \\
\text { Institutional Lock-In of Contractual Failure in } \\
\text { Russia }\end{array}$ & John S. Earle and Klara Z. Sabirianova & June 2000 \\
\hline $\begin{array}{l}\text { No. } 320 \text { Rethinking Marketing Programs for } \\
\text { Emerging Markets }\end{array}$ & Niraj Dawar and Amitava Chattopadhyay & June 2000 \\
\hline $\begin{array}{l}\text { No. } 319 \text { Public Finance and Low Equilibria in } \\
\text { Transition Economies; the Role of Institutions }\end{array}$ & Daniel Daianu and Radu Vranceanu & June 2000 \\
\hline $\begin{array}{l}\text { No. } 318 \text { Some Econometric Evidence on the } \\
\text { Effectiveness of Active Labour Market } \\
\text { Programmes in East Germany }\end{array}$ & Martin Eichler and Michael Lechner & June 2000 \\
\hline $\begin{array}{l}\text { No. } 317 \text { A Model of Russia's "Virtual } \\
\text { Economy" }\end{array}$ & R.E Ericson and B.W Ickes & May 2000 \\
\hline $\begin{array}{l}\text { No. } 316 \text { Financial Institutions, Financial } \\
\text { Contagion, and Financial Crises }\end{array}$ & Haizhou Huang and Chenggang Xu & March 2000 \\
\hline $\begin{array}{l}\text { No. } 315 \text { Privatization versus Regulation in } \\
\text { Developing Economies: The Case of West } \\
\text { African Banks }\end{array}$ & $\begin{array}{l}\text { Jean Paul Azam, Bruno Biais, and } \\
\text { Magueye Dia }\end{array}$ & February 2000 \\
\hline $\begin{array}{l}\text { No. } 314 \text { Is Life More Risky in the Open? } \\
\text { Household Risk-Coping and the Opening of } \\
\text { China's Labor Markets }\end{array}$ & John Giles & April 2000 \\
\hline No. 313 Networks, Migration and Investment: & Abhijit Banerjee and Kaivan Munshi & March 2000 \\
\hline
\end{tabular}

Publications denoted by an asterisk are not available on the Kresge Library webpage (http://www.wdi.bus.umich.edu) 


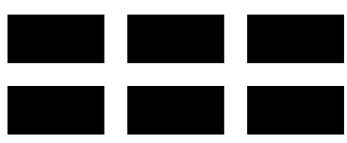

THE WILLIAM DAVIDSON INSTITUTE AT THE UNIVERSITY OF MICHIGAN BUSINESSSCHOOL

\begin{tabular}{|c|c|c|}
\hline $\begin{array}{l}\text { Insiders and Outsiders in Tirupur's } \\
\text { Production Cluster }\end{array}$ & & \\
\hline $\begin{array}{l}\text { No. } 312 \text { Computational Analysis of the Impact } \\
\text { on India of the Uruguay Round and the } \\
\text { Forthcoming WTO Trade Negotiations }\end{array}$ & $\begin{array}{l}\text { Rajesh Chadha, Drusilla K. Brown, Alan } \\
\text { V. Deardorff and Robert M. Stern }\end{array}$ & March 2000 \\
\hline $\begin{array}{l}\text { No. } 311 \text { Subsidized Jobs for Unemployed } \\
\text { Workers in Slovakia }\end{array}$ & Jan. C. van Ours & May 2000 \\
\hline $\begin{array}{l}\text { No. } 310 \text { Determinants of Managerial Pay in } \\
\text { the Czech Republic }\end{array}$ & $\begin{array}{l}\text { Tor Eriksson, Jaromir Gottvald and Pavel } \\
\text { Mrazek }\end{array}$ & May 2000 \\
\hline $\begin{array}{l}\text { No. } 309 \text { The Great Human Capital } \\
\text { Reallocation: An Empirical Analysis of } \\
\text { Occupational Mobility in Transitional Russia }\end{array}$ & Klara Z. Sabirianova & May 2000 \\
\hline $\begin{array}{l}\text { No. } 308 \text { Economic Development, Legality, and } \\
\text { the Transplant Effect }\end{array}$ & $\begin{array}{l}\text { Daniel Berkowitz, Katharina Pistor, and } \\
\text { Jean-Francois Richard }\end{array}$ & February 2000 \\
\hline $\begin{array}{l}\text { No. } 307 \text { Community Participation, Teacher } \\
\text { Effort, and Educational Outcome: The Case of } \\
\text { El Salvador's EDUCO Program }\end{array}$ & Yasuyuki Sawada & November 1999 \\
\hline $\begin{array}{l}\text { No. } 306 \text { Gender Wage Gap and Segregation in } \\
\text { Late Transition }\end{array}$ & Stepan Jurajda & May 2000 \\
\hline $\begin{array}{l}\text { No. } 305 \text { The Gender Pay Gap in the } \\
\text { Transition from Communism: Some Empirical } \\
\text { Evidence }\end{array}$ & Andrew Newell and Barry Reilly & May 2000 \\
\hline $\begin{array}{l}\text { No. } 304 \text { Post-Unification Wage Growth in } \\
\text { East Germany }\end{array}$ & Jennifer Hunt & November 1998 \\
\hline $\begin{array}{l}\text { No. } 303 \text { How Does Privatization Affect } \\
\text { Workers? The Case of the Russian Mass } \\
\text { Privatization Program }\end{array}$ & Elizabeth Brainerd & May 2000 \\
\hline $\begin{array}{l}\text { No. } 302 \text { Liability for Past Environmental } \\
\text { Contamination and Privatization }\end{array}$ & Dietrich Earnhart & March 2000 \\
\hline No. 301 Varieties, Jobs and EU Enlargement & Tito Boeri and Joaquim Oliveira Martins & May 2000 \\
\hline No. 300 Employer Size Effects in Russia & Todd Idson & April 2000 \\
\hline $\begin{array}{l}\text { No. } 299 \text { Information Complements, } \\
\text { Substitutes, and Strategic Product Design }\end{array}$ & $\begin{array}{l}\text { Geoffrey G. Parker and Marshall W. Van } \\
\text { Alstyne }\end{array}$ & March 2000 \\
\hline $\begin{array}{l}\text { No. } 298 \text { Markets, Human Capital, and } \\
\text { Inequality: Evidence from Rural China }\end{array}$ & $\begin{array}{l}\text { Dwayne Benjamin, Loren Brandt, Paul } \\
\text { Glewwe, and Li Guo }\end{array}$ & May 2000 \\
\hline $\begin{array}{l}\text { No. } 297 \text { Corporate Governance in the Asian } \\
\text { Financial Crisis }\end{array}$ & $\begin{array}{l}\text { Simon Johnson, Peter Boone, Alasdair } \\
\text { Breach, and Eric Friedman }\end{array}$ & November 1999 \\
\hline $\begin{array}{l}\text { No. } 296 \text { Competition and Firm Performance: } \\
\text { Lessons from Russia }\end{array}$ & J. David Brown and John S. Earle & March 2000 \\
\hline $\begin{array}{l}\text { No. } 295 \text { Wage Determination in Russia: An } \\
\text { Econometric Investigation }\end{array}$ & Peter J. Luke and Mark E. Schaffer & March 2000 \\
\hline $\begin{array}{l}\text { No. 294: Can Banks Promote Enterprise } \\
\text { Restructuring?: Evidence From a Polish } \\
\text { Bank's Experience }\end{array}$ & John P. Bonin and Bozena Leven & March 2000 \\
\hline $\begin{array}{l}\text { No. 293: Why do Governments Sell Privatised } \\
\text { Companies Abroad? }\end{array}$ & $\begin{array}{l}\text { Bernardo Bortolotti, Marcella Fantini and } \\
\text { Carlo Scarpa }\end{array}$ & March 2000 \\
\hline $\begin{array}{l}\text { No. 292: Going Public in Poland: Case-by- } \\
\text { Case Privatizations, Mass Privatization and } \\
\text { Private Sector Initial Public Offerings }\end{array}$ & Wolfgang Aussenegg & December 1999 \\
\hline $\begin{array}{l}\text { No. 291: Institutional Technology and the } \\
\text { Chains of Trust: Capital Markets and }\end{array}$ & Bruce Kogut and Andrew Spicer & March 1999 \\
\hline
\end{tabular}

Publications denoted by an asterisk are not available on the Kresge Library webpage (http://www.wdi.bus.umich.edu) 


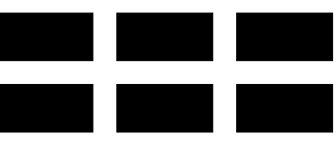

THE WILLIAM DAVIDSON INSTITUTE

AT THE UNIVERSITY OF MICHIGAN BUSINESSSCHOOL

\begin{tabular}{|c|c|c|}
\hline $\begin{array}{l}\text { Privatization in Russia and the Czech } \\
\text { Republic }\end{array}$ & & \\
\hline $\begin{array}{l}\text { No. 290: Banking Crises and Bank Rescues: } \\
\text { The Effect of Reputation }\end{array}$ & Jenny Corbett and Janet Mitchell & January 2000 \\
\hline $\begin{array}{l}\text { No. 289: Do Active Labor Market Policies } \\
\text { Help Unemployed Workers to Find and Keep } \\
\text { Regular Jobs? }\end{array}$ & Jan C. van Ours & February 2000 \\
\hline $\begin{array}{l}\text { No. 288: Consumption Patterns of the New } \\
\text { Elite in Zimbabwe }\end{array}$ & Russell Belk & February 2000 \\
\hline $\begin{array}{l}\text { No. 287: Barter in Transition Economies: } \\
\text { Competing Explanations Confront Ukranian } \\
\text { Data }\end{array}$ & $\begin{array}{l}\text { Dalia Marin, Daniel Kaufmann and } \\
\text { Bogdan Gorochowskij }\end{array}$ & January 2000 \\
\hline $\begin{array}{l}\text { No. 286: The Quest for Pension Reform: } \\
\text { Poland's Security through Diversity }\end{array}$ & Marek Góra and Michael Rutkowski & January 2000 \\
\hline $\begin{array}{l}\text { No. 285: Disorganization and Financial } \\
\text { Collapse }\end{array}$ & Dalia Marin and Monika Schnitzer & October 1999 \\
\hline $\begin{array}{l}\text { No. 284: Coordinating Changes in } M \text {-form } \\
\text { and U-form Organizations }\end{array}$ & $\begin{array}{l}\text { Yingyi Qian, Gérard Roland and } \\
\text { Chenggang } \mathrm{Xu}\end{array}$ & May 1999 \\
\hline $\begin{array}{l}\text { No. 283: Why Russian Workers Do Not Move: } \\
\text { Attachment of Workers Through In-Kind } \\
\text { Payments }\end{array}$ & Guido Friebel and Sergei Guriev & October 1999 \\
\hline $\begin{array}{l}\text { No. 282: Lessons From Fiascos in Russian } \\
\text { Corporate Governance }\end{array}$ & Merritt B. Fox and Michael A. Heller & October 1999 \\
\hline $\begin{array}{l}\text { No. 281: Income Distribution and Price } \\
\text { Controls: Targeting a Social Safety Net } \\
\text { During Economic Transition }\end{array}$ & Michael Alexeev and James Leitzel & March 1999 \\
\hline $\begin{array}{l}\text { No. 280: Starting Positions, Reform Speed, } \\
\text { and Economic Outcomes in Transitioning } \\
\text { Economies }\end{array}$ & William Hallagan and Zhang Jun & January 2000 \\
\hline No. 279 : The Value of Prominent Directors & Yoshiro Miwa \& J. Mark Ramseyer & October 1999 \\
\hline No. 278: The System Paradigm & János Kornai & April 1998 \\
\hline $\begin{array}{l}\text { No. 277: The Developmental Consequences of } \\
\text { Foreign Direct Investment in the Transition } \\
\text { from Socialism to Capitalism: The } \\
\text { Performance of Foreign Owned Firms in } \\
\text { Hungary }\end{array}$ & Lawrence Peter King & September 1999 \\
\hline $\begin{array}{l}\text { No. 276: Stability and Disorder: An } \\
\text { Evolutionary Analysis of Russia's Virtual } \\
\text { Economy }\end{array}$ & Clifford Gaddy and Barry W. Ickes & November 1999 \\
\hline $\begin{array}{l}\text { No. 275: Limiting Government Predation } \\
\text { Through Anonymous Banking: A Theory with } \\
\text { Evidence from China. }\end{array}$ & $\begin{array}{l}\text { Chong-En Bai, David D. Li, Yingyi Qian } \\
\text { and Yijiang Wang }\end{array}$ & July 1999 \\
\hline *No. 274: Transition with Labour Supply & Tito Boeri & December 1999 \\
\hline $\begin{array}{l}\text { No. 273: Sectoral Restructuring and Labor } \\
\text { Mobility: A Comparative Look at the Czech } \\
\text { Republic }\end{array}$ & Vit Sorm and Katherine Terrell & November 1999 \\
\hline $\begin{array}{l}\text { *No. 272: Published in: Journal of } \\
\text { Comparative Economics "Returns to Human } \\
\text { Capital Under the Communist Wage Grid and } \\
\text { During the Transition to a Market Economy" } \\
\text { Vol. 27, pp. 33-60 1999. }\end{array}$ & $\begin{array}{l}\text { Daniel Munich, Jan Svejnar and Katherine } \\
\text { Terrell }\end{array}$ & October 1999 \\
\hline
\end{tabular}

Publications denoted by an asterisk are not available on the Kresge Library webpage (http://www.wdi.bus.umich.edu) 


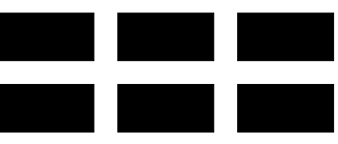

THE WILLIAM DAVIDSON INSTITUTE AT THE UNIVERSITY OF MICHIGAN BUSINESSSCHOOL

\begin{tabular}{|c|c|c|}
\hline $\begin{array}{l}\text { No. 271: Barter in Russia: Liquidity Shortage } \\
\text { Versus Lack of Restructuring }\end{array}$ & Sophie Brana and Mathilde Maurel & June 1999 \\
\hline $\begin{array}{l}\text { No. 270: Tests for Efficient Financial } \\
\text { Intermediation with Application to China }\end{array}$ & Albert Park and Kaja Sehrt & March 1999 \\
\hline $\begin{array}{l}\text { No. } 269 \text { a: Russian Privatization and } \\
\text { Corporate Governance: What Went Wrong? }\end{array}$ & $\begin{array}{l}\text { Bernard Black, Reinier Kraakman and } \\
\text { Anna Tarassova }\end{array}$ & May 2000 \\
\hline $\begin{array}{l}\text { No. 269: Russian Privatization and Corporate } \\
\text { Governance: What Went Wrong? }\end{array}$ & $\begin{array}{l}\text { Bernard Black, Reinier Kraakman and } \\
\text { Anna Tarassova }\end{array}$ & September 1999 \\
\hline $\begin{array}{l}\text { No. 268: Are Russians Really Ready for } \\
\text { Capitalism? }\end{array}$ & Susan Linz & September 1999 \\
\hline $\begin{array}{l}\text { No. 267: Do Stock Markets Promote } \\
\text { Economic Growth? }\end{array}$ & $\begin{array}{l}\text { Randall K. Filer, Jan Hanousek and Nauro } \\
\text { Campos }\end{array}$ & September 1999 \\
\hline $\begin{array}{l}\text { No. 266: Objectivity, Proximity and } \\
\text { Adaptability in Corporate Governance }\end{array}$ & Arnoud W.A Boot and Jonathan R. Macey & September 1999 \\
\hline $\begin{array}{l}\text { No. 265: When the Future is not What it Used } \\
\text { to Be: Lessons from the Western European } \\
\text { Experience to Forecasting Education and } \\
\text { Training in Transitional Economies }\end{array}$ & $\begin{array}{l}\text { Nauro F. Campos, Gerard Hughes, Stepan } \\
\text { Jurajda, and Daniel Munich }\end{array}$ & September 1999 \\
\hline $\begin{array}{l}\text { No. 264: The Institutional Foundation of } \\
\text { Foreign-Invested Enterprises (FIEs) in China }\end{array}$ & Yasheng Huang & September 1999 \\
\hline $\begin{array}{l}\text { No. 263: The Changing Corporate } \\
\text { Governance Paradigm: Implications for } \\
\text { Transition and Developing Countries }\end{array}$ & $\begin{array}{l}\text { Erik Berglof and Ernst-Ludwig von } \\
\text { Thadden }\end{array}$ & June 1999 \\
\hline No. 262: Law Enforcement and Transition & Gerard Roland and Thierry Verdier & May 1999 \\
\hline $\begin{array}{l}\text { No. 261: Soft Budget Constraints, Pecuniary } \\
\text { Externality, and the Dual Track System }\end{array}$ & Jiahua Che & June 2000 \\
\hline $\begin{array}{l}\text { No. 260: Missing Market in Labor Quality: } \\
\text { The Role of Quality Markets in Transiton }\end{array}$ & Gary H. Jefferson & July 1999 \\
\hline $\begin{array}{l}\text { No. 259: Do Corporate Global Environmental } \\
\text { Standards in Emerging Markets Create or } \\
\text { Destroy Market Value }\end{array}$ & $\begin{array}{l}\text { Glen Dowell, Stuart Hart and Bernard } \\
\text { Yeung }\end{array}$ & June 1999 \\
\hline $\begin{array}{l}\text { No. 258: Public Training and Outflows from } \\
\text { Unemployment }\end{array}$ & Patrick A. Puhani & June 1999 \\
\hline $\begin{array}{l}\text { No. 257: Ownership Versus Environment: } \\
\text { Why are Public Sector Firms Ineffecient? }\end{array}$ & Ann P. Bartel and Ann E. Harrison & June 1999 \\
\hline $\begin{array}{l}\text { No. 256: Taxation and Evasion in the } \\
\text { Presence of Exortion by Organized Crime }\end{array}$ & $\begin{array}{l}\text { Michael Alexeev, Eckhard Janeba and } \\
\text { Stefan Osborne }\end{array}$ & November 1999 \\
\hline $\begin{array}{l}\text { No. 255: Revisiting Hungary's Bankruptcy } \\
\text { Episode }\end{array}$ & John P. Bonin and Mark E. Schaffer & September 1999 \\
\hline $\begin{array}{l}\text { No. 254: FDI in Emerging Markets: A Home- } \\
\text { Country View }\end{array}$ & Marina v.N Whitman & June 1999 \\
\hline $\begin{array}{l}\text { No. 253: The Asian Financial Crisis: What } \\
\text { Happened, and What is to be Done }\end{array}$ & Jeffrey D. Sachs and Wing Thye Woo & January 1999 \\
\hline $\begin{array}{l}\text { No. 252: Organizational Law as Asset } \\
\text { Partitioning }\end{array}$ & Henry Hansmann and Reinier Kraakman & September 1999 \\
\hline $\begin{array}{l}\text { No. 251: Consumer Behavior Research in } \\
\text { Emerging Consumer Markets: the Case of the } \\
\text { Optimum Stimulation Level in South Africa }\end{array}$ & $\begin{array}{l}\text { Jan-Benedict E. M. Steenkamp and Steven } \\
\text { M. Burgess }\end{array}$ & September 1999 \\
\hline $\begin{array}{l}\text { No. 250: Property Rights Formation and the } \\
\text { Organization of Exchange and Production in } \\
\text { Rural China }\end{array}$ & $\begin{array}{l}\text { Matthew A. Turner, Loren Brandt, and } \\
\text { Scott Rozelle }\end{array}$ & July 1998 \\
\hline
\end{tabular}

Publications denoted by an asterisk are not available on the Kresge Library webpage (http://www.wdi.bus.umich.edu) 


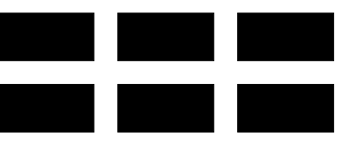

THE WILliam DAVIDSON InSTITUTE AT THE UNIVERSITY OF MICHIGAN BUSINESSSCHOOL

\begin{tabular}{|c|c|c|}
\hline $\begin{array}{l}\text { No. 249: Impacts of the Indonesian Economic } \\
\text { Crisis: Price Changes and the Poor }\end{array}$ & $\begin{array}{l}\text { James Levinsohn, Steven Berry, and Jed } \\
\text { Friedman }\end{array}$ & June 1999 \\
\hline $\begin{array}{l}\text { No. 248: Internal Barriers in the Transition of } \\
\text { Enterprises from Central Plan to Market }\end{array}$ & Charalambos Vlachoutsicos & July 1999 \\
\hline $\begin{array}{l}\text { No. 247: Spillovers from Multinationals in } \\
\text { Developing Countries: the Mechanisms at } \\
\text { Work }\end{array}$ & Richard E. Caves & June 1999 \\
\hline $\begin{array}{l}\text { No. 246: Dynamism and Inertia on the } \\
\text { Russian Labour Market: A Model of } \\
\text { Segmentation }\end{array}$ & $\begin{array}{l}\text { Irena Grosfeld, Claudia Senik-Leygonie, } \\
\text { Thierry Verdier, Stanislav Kolenikov and } \\
\text { Elena Paltseva }\end{array}$ & May 1999 \\
\hline $\begin{array}{l}\text { No. 245: Lessons from Bank Privatization in } \\
\text { Central Europe }\end{array}$ & John Bonin and Paul Wachtel & May 1999 \\
\hline $\begin{array}{l}\text { No. 244: Nominal-Real Tradeoffs and the } \\
\text { Effects of Monetary Policy: the Romanian } \\
\text { Experience }\end{array}$ & Christian Popa & December 1998 \\
\hline $\begin{array}{l}\text { No. 243: Privatization, Political Risk and } \\
\text { Stock Market Development in Emerging } \\
\text { Economies }\end{array}$ & Enrico C. Perotti and Pieter van Oijen & March 1999 \\
\hline $\begin{array}{l}\text { No. 242: Investment Financing in Russian } \\
\text { Financial-Industrial Groups }\end{array}$ & Enrico C. Perotti and Stanislav Gelfer & October 1998 \\
\hline $\begin{array}{l}\text { No. 241: Can governments maintain hard } \\
\text { budget constraints? Bank lending and } \\
\text { financial isolation in Romania }\end{array}$ & $\begin{array}{l}\text { Octavian Carare, Constantijn Claessens, } \\
\text { Enrico } C . \text { Perotti }\end{array}$ & January 1999 \\
\hline $\begin{array}{l}\text { No. 240: Democratic Institutions and } \\
\text { Economic Reform: the Polish Case }\end{array}$ & $\begin{array}{l}\text { John E. Jackson, Jacek Klich, and } \\
\text { Krystyna Poznanska }\end{array}$ & April 1998 \\
\hline $\begin{array}{l}\text { No. 239: A Longitudinal Study of IJV } \\
\text { Performance in Eastern Europe }\end{array}$ & Keith D. Brouthers and Gary Bamossy & June 1999 \\
\hline $\begin{array}{l}\text { No. 238: Published in: Journal of Business } \\
\text { Venturing, "Firm Creation and Economic } \\
\text { Transitions" Vol. 14, Iss. 5, } 6 \text { Sep/Nov 1999, } \\
\text { pp. 427-450. }\end{array}$ & $\begin{array}{l}\text { John E. Jackson, Jacek Klich, Krystyna } \\
\text { Poznanska }\end{array}$ & July 1998 \\
\hline $\begin{array}{l}\text { No. 237: Analysis of Entrepreneurial Attitudes } \\
\text { in Poland }\end{array}$ & $\begin{array}{l}\text { John E. Jackson and Aleksander S. } \\
\text { Marcinkowski }\end{array}$ & March 1997 \\
\hline $\begin{array}{l}\text { No. 236: Investment and Finance in De Novo } \\
\text { Private Firms: Empirical Results from the } \\
\text { Czech Republic, Hungary, and Poland }\end{array}$ & $\begin{array}{l}\text { Andrzej Bratkowski, Irena Grosfeld, Jacek } \\
\text { Rostowski }\end{array}$ & April 1999 \\
\hline $\begin{array}{l}\text { No. 235: Does a Soft Macroeconomic } \\
\text { Environment Induce Restructuring on the } \\
\text { Microeconomic Level during the Transition } \\
\text { Period? Evidence from Investment Behavior } \\
\text { of Czech Enterprises }\end{array}$ & Lubomír Lízal & June 1999 \\
\hline $\begin{array}{l}\text { No. 234: Banking Reform in China: Gradually } \\
\text { Strengthening Pillar or Fragile Reed? }\end{array}$ & John Bonin & June 1999 \\
\hline $\begin{array}{l}\text { No. 233: Theories of Soft Budget Constraints } \\
\text { and the Analysis of Banking Crises }\end{array}$ & Janet Mitchell & March 1999 \\
\hline $\begin{array}{l}\text { No. 232: Unemployment Risk, Precautionary } \\
\text { Savings, and Moonlighting in Russia }\end{array}$ & $\begin{array}{l}\text { Alessandra Guariglia and Byung-Yeon } \\
\text { Kim }\end{array}$ & June 1999 \\
\hline $\begin{array}{l}\text { No. 231: Investing in Turbulent Times: The } \\
\text { Investment Behavior of Polish Firms in the } \\
\text { Transition }\end{array}$ & $\begin{array}{l}\text { Josef C. Brada, Arthur E. King, and Chia- } \\
\text { Ying Ma }\end{array}$ & April 1999 \\
\hline $\begin{array}{l}\text { No. 230: The End of Moderate Inflation in } \\
\text { Three Transition Economies? }\end{array}$ & Josef C. Brada and Ali M. Kutan & April 1999 \\
\hline
\end{tabular}

Publications denoted by an asterisk are not available on the Kresge Library webpage (http://www.wdi.bus.umich.edu) 


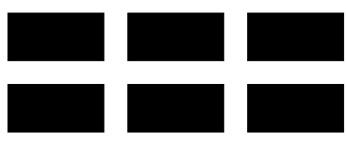

THE WILLIAM DAVIDSON INSTITUTE

AT THE UNIVERSITY OF MICHIGAN BUSINESSSCHOOL

\begin{tabular}{|c|c|c|}
\hline $\begin{array}{l}\text { No. 229: Back to the Future: The Growth } \\
\text { Prospects of Transition Economies } \\
\text { Reconsidered }\end{array}$ & Nauro F. Campos & April 1999 \\
\hline $\begin{array}{l}\text { No. 228: The Enterprise Isolation Program in } \\
\text { Russia }\end{array}$ & Simeon Djankov & April 1999 \\
\hline $\begin{array}{l}\text { No. 227: Published in: Journal of } \\
\text { Comparative Economics, "Ownership } \\
\text { Concentration and Corporate Performance in } \\
\text { the Czech Republic" 27(3), September 1999, } \\
\text { pp. 498-513. }\end{array}$ & Stijn Claessens and Simeon Djankov & April 1999 \\
\hline $\begin{array}{l}\text { No. 226: Unemployment Benefit Entitlement } \\
\text { and Training Effects in Poland during } \\
\text { Transition }\end{array}$ & Patrick A. Puhani & March 1999 \\
\hline $\begin{array}{l}\text { No. 225: Transition at Whirlpool-Tatramat: } \\
\text { Case Studies }\end{array}$ & Hans Brechbuhl and Sonia Ferencikova & March 1999 \\
\hline $\begin{array}{l}\text { No. 224: Measuring Progress in Transition } \\
\text { and Towards EU Accession: A Comparison of } \\
\text { Manufacturing Firms in Poland, Romania, } \\
\text { and Spain }\end{array}$ & $\begin{array}{l}\text { Wendy Carlin, Saul Estrin, and Mark } \\
\text { Schaffer }\end{array}$ & March 1999 \\
\hline $\begin{array}{l}\text { No. 223: Product Market Competition in } \\
\text { Transition Economies: Increasing Varieties } \\
\text { and Consumer Loyalty }\end{array}$ & Mitsutoshi M. Adachi & March 1999 \\
\hline $\begin{array}{l}\text { No. 222: Opaque Markets and Rapid Growth: } \\
\text { the Superiority of Bank-Centered Financial } \\
\text { Systems for Developing Nations }\end{array}$ & Rodney Wallace & July 1999 \\
\hline $\begin{array}{l}\text { No. 221: Technology Spillovers through } \\
\text { Foreign Direct Investment }\end{array}$ & Yuko Kinoshita & January 1999 \\
\hline $\begin{array}{l}\text { No. 220: Managerial, Expertise and Team } \\
\text { Centered Forms of Organizing: A Cross- } \\
\text { Cultural Exploration of Independence in } \\
\text { Engineering Work }\end{array}$ & Leslie Perlow & January 1999 \\
\hline $\begin{array}{l}\text { No. 219: Household Structure and Labor } \\
\text { Demand in Agriculture: Testing for } \\
\text { Separability in Rural China }\end{array}$ & Audra J. Bowlus and Terry Sicular & January 1999 \\
\hline $\begin{array}{l}\text { No. 218: Competing Strategies of FDI and } \\
\text { Technology Transfer to China: American and } \\
\text { Japanese Firms }\end{array}$ & W. Mark Fruin and Penelope Prime & January 1999 \\
\hline $\begin{array}{l}\text { No. } 217 \text { Published in: Journal of } \\
\text { Comparative Economics, "Returns to } \\
\text { Mobility in the Transition to a Market } \\
\text { Economy" Vol. 27, No. 1, March 1999, pp. 4- }\end{array}$ & Tito Boeri and Christopher J. Flinn & January 1999 \\
\hline $\begin{array}{l}\text { No. } 216 \text { Published in: Journal of } \\
\text { Comparative Economics, "Labor Market } \\
\text { Policies and Unemployment in the Czech } \\
\text { Republic." Vol. 27, No. 1, March 1999, pp. } \\
\text { 33-60. }\end{array}$ & Katherine Terrell and Vit Sorm & November 1998 \\
\hline $\begin{array}{l}\text { No. } 215 \text { Published in: Journal of } \\
\text { Comparative Economics, “Active Labor } \\
\text { Market Policies in Poland: Human Capital } \\
\text { Enhancement, Stigmatization or Benefit } \\
\text { Churning?” Vol. 27, No. 1, March 1999, pp. } \\
\text { 61- }\end{array}$ & $\begin{array}{l}\text { Jochen Kluve, Hartmut Lehmann, and } \\
\text { Christoph M. Schmidt }\end{array}$ & December 1998 \\
\hline
\end{tabular}

Publications denoted by an asterisk are not available on the Kresge Library webpage (http://www.wdi.bus.umich.edu) 


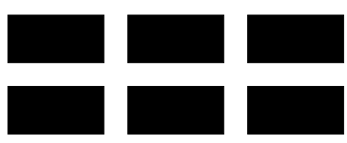

THE WILLIAM DAVIDSON INSTITUTE

AT THE UNIVERSITY OF MICHIGAN BUSINESSSCHOOL

\begin{tabular}{|c|c|c|}
\hline $\begin{array}{l}\text { No. } 214 \text { Published in: Journal of } \\
\text { Comparative Economics, “Does the Slovenian } \\
\text { Public Work Program Increase Participants' } \\
\text { Chances to Find a Job?” Vol. 27, No.1, } \\
\text { March 1999, pp. 113- }\end{array}$ & Milan Vodopivec & December 1998 \\
\hline $\begin{array}{l}\text { No. } 213 \text { Published in: Journal of } \\
\text { Comparative Economics, "Effects of Active } \\
\text { Labor Market Programs on the Transition } \\
\text { Rate from Unemployment into Regular Jobs in } \\
\text { the Slovak Republic." Vol. 27, No. 1, March } \\
\text { 1999, pp. 90- }\end{array}$ & Martina Lubyova and Jan C. van Ours & December 1998 \\
\hline $\begin{array}{l}\text { No. 212: The Marketing System in Bulgarian } \\
\text { Livestock Production - The Present State and } \\
\text { Evolutionary Processes During the Period of } \\
\text { Economic Transition }\end{array}$ & Yordan Staykov, Team Leader & October 1998 \\
\hline $\begin{array}{l}\text { No. 211: Bankruptcy Experience in Hungary } \\
\text { and the Czech Republic }\end{array}$ & Janet Mitchell & October 1998 \\
\hline $\begin{array}{l}\text { No 210: Values, Optimum Stimulation Levels } \\
\text { and Brand Loyalty: New Scales in New } \\
\text { Populations }\end{array}$ & Steven M. Burgess and Mari Harris & September 1998 \\
\hline $\begin{array}{l}\text { No. 209: Inherited Wealth, Corporate Control } \\
\text { and Economic Growth }\end{array}$ & $\begin{array}{l}\text { Randall K. Morck, David A. Stangeland, } \\
\text { and Bernard Yeung }\end{array}$ & September 1998 \\
\hline $\begin{array}{l}\text { No. 208: A Cultural Analysis of Homosocial } \\
\text { Reproduction and Contesting Claims to } \\
\text { Competence in Transitional Firms }\end{array}$ & Michael D. Kennedy & July 1998 \\
\hline $\begin{array}{l}\text { No. 207: From Survival to Success: The } \\
\text { Journey of Corporate Transformation at } \\
\text { Haier. Forthcoming in Teaching the } \\
\text { Dinosaurs to Dance: Organizational Change } \\
\text { in Transition Economies ed. Daniel Denison. } \\
\text { No. 206: Why Do People Work If They Are } \\
\text { Not Paid? An Example from Eastern Europe. } \\
\text { Forthcoming in Teaching the Dinosaurs to } \\
\text { Dance: Organizational Change in Transition } \\
\text { Economies ed. Daniel Denison. }\end{array}$ & Arthur Yeung and Kenneth DeWoskin & $\begin{array}{l}\text { July } 1998 \\
\text { May } 1998\end{array}$ \\
\hline $\begin{array}{l}\text { No. 205: Firm Ownership and Work } \\
\text { Motivation in Bulgaria and Hungary: An } \\
\text { Empirical Study of the Transition in the Mid- } \\
\text { 1990s. Forthcoming in Teaching the } \\
\text { Dinosaurs to Dance: Organizational Change } \\
\text { in Transition Economies ed. Daniel Denison. }\end{array}$ & $\begin{array}{l}\text { Robert A. Roe, Irina L. Zinovieva, } \\
\text { Elizabeth Dienes, and Laurens A. ten Horn }\end{array}$ & May 1998 \\
\hline $\begin{array}{l}\text { No. 204: Human Resource Management in the } \\
\text { Restructuring of Chinese Joint Ventures. } \\
\text { Forthcoming in Teaching the Dinosaurs to } \\
\text { Dance: Organizational Change in Transition } \\
\text { Economies ed. Daniel Denison. }\end{array}$ & Nandani Lynton & April 1998 \\
\hline $\begin{array}{l}\text { No. 203: Emergent Compensation Strategies } \\
\text { in Post-Socialist Poland: Understanding the } \\
\text { Cognitive Underpinnings of Management } \\
\text { Practices in a Transition Economy. } \\
\text { Forthcoming in Teaching the Dinosaurs to } \\
\text { Dance: Organizational Change in Transition }\end{array}$ & Marc Weinstein & March 1998 \\
\hline
\end{tabular}

Publications denoted by an asterisk are not available on the Kresge Library webpage (http://www.wdi.bus.umich.edu) 


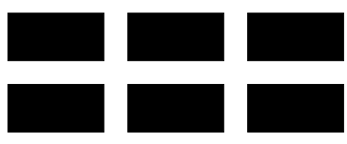

THE WILLIAM DAVIDSON INSTITUTE

AT THE UNIVERSITY OF MICHIGAN BUSINESSSCHOOL

\begin{tabular}{|c|c|c|}
\hline Economies ed. Daniel Denison. & & \\
\hline $\begin{array}{l}\text { No. 202: Corporate Transformation and } \\
\text { Organizational Learning: The People's } \\
\text { Republic of China. Forthcoming in Teaching } \\
\text { the Dinosaurs to Dance: Organizational } \\
\text { Change in Transition Economies ed. Daniel } \\
\text { Denison. }\end{array}$ & Meinolf Dierkes and Zhang Xinhua & March 1998 \\
\hline $\begin{array}{l}\text { No. 201: Foreign Direct Investment as a } \\
\text { Factor of Change: The Case of Slovakia. } \\
\text { Forthcoming in Teaching the Dinosaurs to } \\
\text { Dance: Organizational Change in Transition } \\
\text { Economies ed. Daniel Denison. }\end{array}$ & Sonia Ferencikova & February 1998 \\
\hline $\begin{array}{l}\text { No. 200: Radical versus Incremental Change: } \\
\text { The Role of Capabilities, Competition, and } \\
\text { Leaders. Forthcoming in Teaching the } \\
\text { Dinosaurs to Dance: Organizational Change } \\
\text { in Transition Economies ed. Daniel Denison. }\end{array}$ & Karen L. Newman & February 1998 \\
\hline $\begin{array}{l}\text { No. 199: The Emergence of Market Practices } \\
\text { in China's Economic Transition: Price Setting } \\
\text { Practices in Shanghai's Industrial Firms. } \\
\text { Forthcoming in Teaching the Dinosaurs to } \\
\text { Dance: Organizational Change in Transition } \\
\text { Economies ed. Daniel Denison. }\end{array}$ & Douglas Guthrie & February 1998 \\
\hline $\begin{array}{l}\text { No. 198: The Application of Change } \\
\text { Management Methods at Business } \\
\text { Organizations Operating in Hungary: } \\
\text { Challenges in the Business and Cultural } \\
\text { Environment and First Practical Experiences. } \\
\text { Forthcoming in Teaching the Dinosaurs to } \\
\text { Dance: Organizational Change in Transition } \\
\text { Economies ed. Daniel Denison. }\end{array}$ & Dr. János Fehér & January 1998 \\
\hline $\begin{array}{l}\text { No. 197: Organizational Changes in Russian } \\
\text { Industrial Enterprises: Mutation of Decision- } \\
\text { Making Structures and Transformations of } \\
\text { Ownership. Forthcoming in Teaching the } \\
\text { Dinosaurs to Dance: Organizational Change } \\
\text { in Transition Economies ed. Daniel Denison. }\end{array}$ & Igor B. Gurkov & January 1998 \\
\hline $\begin{array}{l}\text { No. 196: Understanding and Managing } \\
\text { Challenges to the Romanian Companies } \\
\text { during Transition. Forthcoming in Teaching } \\
\text { the Dinosaurs to Dance: Organizational } \\
\text { Change in Transition Economies ed. Daniel } \\
\text { Denison. }\end{array}$ & Dan Candea and Rodica M. Candea & January 1998 \\
\hline $\begin{array}{l}\text { No. 195: Insider Lending and Economic } \\
\text { Transition: The Structure, Function, and } \\
\text { Performance Impact of Finance Companies in } \\
\text { Chinese Business Groups. Forthcoming in } \\
\text { Teaching the Dinosaurs to Dance: } \\
\text { Organizational Change in Transition } \\
\text { Economies ed. Daniel Denison. }\end{array}$ & Lisa A. Keister & December 1997 \\
\hline $\begin{array}{l}\text { No. 194: Japanese Investment in Transitional } \\
\text { Economies: Characteristics and Performance. }\end{array}$ & Paul W. Beamish and Andrew Delios & November 1997 \\
\hline
\end{tabular}

Publications denoted by an asterisk are not available on the Kresge Library webpage (http://www.wdi.bus.umich.edu) 


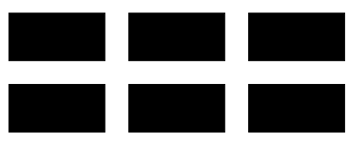

THE WILLIAM DAVIDSON INSTITUTE

AT THE UNIVERSITY OF MICHIGAN BUSINESSSCHOOL

\begin{tabular}{|c|c|c|}
\hline $\begin{array}{l}\text { Forthcoming in Teaching the Dinosaurs to } \\
\text { Dance: Organizational Change in Transition } \\
\text { Economies ed. Daniel Denison. }\end{array}$ & & \\
\hline $\begin{array}{l}\text { No. 193: Building Successful Companies in } \\
\text { Transition Economies. Forthcoming in } \\
\text { Teaching the Dinosaurs to Dance: } \\
\text { Organizational Change in Transition } \\
\text { Economies ed. Daniel Denison. }\end{array}$ & Dr. Ivan Perlaki & January 1998 \\
\hline $\begin{array}{l}\text { No. 192: Russian Communitariansim: An } \\
\text { Invisible Fist in the Transformation Process of } \\
\text { Russia. Forthcoming in Teaching the } \\
\text { Dinosaurs to Dance: Organizational Change } \\
\text { in Transition Economies ed. Daniel Denison. }\end{array}$ & Charalambos Vlachoutsicos & July 1998 \\
\hline No. 191: Teaching the Dinosaurs to Dance & Michal Cakrt & September 1997 \\
\hline $\begin{array}{l}\text { No. 190: Strategic Restructuring: Making } \\
\text { Capitalism in Post-Communist Eastern } \\
\text { Europe. Forthcoming in Teaching the } \\
\text { Dinosaurs to Dance: Organizational Change } \\
\text { in Transition Economies ed. Daniel Denison. }\end{array}$ & Lawrence P. King & September 1997 \\
\hline $\begin{array}{l}\text { No. 189: Published in: Regional Science and } \\
\text { Urban Economics, "Russia's Internal } \\
\text { Border”, } 29 \text { (5), September } 1999 .\end{array}$ & Daniel Berkowitz and David N. DeJong & July 1998 \\
\hline $\begin{array}{l}\text { No. 187: Corporate Structure and } \\
\text { Performance in Hungary }\end{array}$ & László Halpern and Gábor Kórsöi & July 1998 \\
\hline $\begin{array}{l}\text { No. 186: Performance of Czech Companies by } \\
\text { Ownership Structure }\end{array}$ & Andrew Weiss and Georgiy Nikitin & June 1998 \\
\hline $\begin{array}{l}\text { No. 185: Firm Performance in Bulgaria and } \\
\text { Estonia: The effects of competitive pressure, } \\
\text { financial pressure and disorganisation }\end{array}$ & Jozef Konings & July 1998 \\
\hline $\begin{array}{l}\text { No. 184: Investment and Wages during the } \\
\text { Transition: Evidence from Slovene Firms }\end{array}$ & Janez Prasnikar and Jan Svejnar & July 1998 \\
\hline $\begin{array}{l}\text { No. 183: Investment Portfolio under Soft } \\
\text { Budget: Implications for Growth, Volatility } \\
\text { and Savings }\end{array}$ & Chongen Bai and Yijiang Wang & \\
\hline $\begin{array}{l}\text { No. 181: Delegation and Delay in Bank } \\
\text { Privatization }\end{array}$ & Loránd Ambrus-Lakatos and Ulrich Hege & July 1998 \\
\hline $\begin{array}{l}\text { No. 180: Financing Mechanisms and } R \& D \\
\text { Investment }\end{array}$ & Haizhou Huang and Chenggang Xu & July 1998 \\
\hline $\begin{array}{l}\text { No. 179: Organizational Culture and } \\
\text { Effectiveness: The Case of Foreign Firms in } \\
\text { Russia }\end{array}$ & Carl F. Fey and Daniel R. Denison & January 1999 \\
\hline $\begin{array}{l}\text { No. 178: Output and Unemployment } \\
\text { Dynamics in Transition }\end{array}$ & Vivek H. Dehejia and Douglas W. Dwyer & January 1998 \\
\hline $\begin{array}{l}\text { No. 177: Published in: Economics of } \\
\text { Transition,, “Bureaucracies in the Russian } \\
\text { Voucher Privatization" Vol. } 8, \text { No. 1, 2000, } \\
\text { pp. 37-57. }\end{array}$ & Guido Friebel & June 1998 \\
\hline $\begin{array}{l}\text { No. 176: Chronic Moderate Inflation in } \\
\text { Transition: The Tale of Hungary }\end{array}$ & János Vincze & June 1998 \\
\hline $\begin{array}{l}\text { No. 175: Privatisation and Market Structure } \\
\text { in a Transition Economy }\end{array}$ & John Bennett and James Maw & June 1998 \\
\hline No. 174: Ownership and Managerial & Patrick Bolton and Chenggang $X u$ & June 1998 \\
\hline
\end{tabular}

Publications denoted by an asterisk are not available on the Kresge Library webpage

(http://www.wdi.bus.umich.edu) 


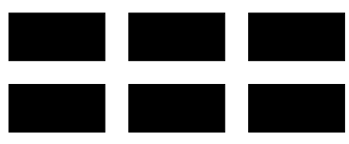

THE WILLIAM DAVIDSON INSTITUTE

AT THE UNIVERSITY OF MICHIGAN BUSINESSSCHOOL

\begin{tabular}{|c|c|c|}
\hline $\begin{array}{l}\text { Competition: Employee, Customer, or Outside } \\
\text { Ownership }\end{array}$ & & \\
\hline $\begin{array}{l}\text { No. 173: Intragovernment Procurement of } \\
\text { Local Public Good: A Theory of } \\
\text { Decentralization in Nondemocratic } \\
\text { Government }\end{array}$ & Chong-en Bai, Yu Pan and Yijiang Wang & June 1998 \\
\hline $\begin{array}{l}\text { No. 172: Political Instability and Growth in } \\
\text { Proprietary Economies }\end{array}$ & Jody Overland and Michael Spagat & August 1998 \\
\hline $\begin{array}{l}\text { No. 171: Published in Post-Communist } \\
\text { Economies, "Framework Issues in the } \\
\text { Privatization Strategies of the Czech Republic, } \\
\text { Hungary, and Poland" Vol. 11, no. } 1 \text { March } \\
\text { 1999. }\end{array}$ & Morris Bornstein & June 1998 \\
\hline $\begin{array}{l}\text { No. 170: Published in: European Journal of } \\
\text { Political Economy "Privatization, Ownership } \\
\text { Structure and Transparency: How to Measure } \\
\text { a Real Involvement of the State" 15(4), } \\
\text { November 1999, pp. 605-18. }\end{array}$ & Frantisek Turnovec & May 1998 \\
\hline $\begin{array}{l}\text { No. } 169 \text { Published in: American Economic } \\
\text { Review, “Unemployment and the Social Safety } \\
\text { Net during Transitions to a Market Economy: } \\
\text { Evidence from Czech and Slovak Men." Vol. } \\
\text { 88, No. 5, Dec. 1998, pp. 1117-1142. }\end{array}$ & $\begin{array}{l}\text { John C. Ham, Jan Svejnar, and Katherine } \\
\text { Terrell }\end{array}$ & December 1998 \\
\hline $\begin{array}{l}\text { No. 167: Voucher Privatization with } \\
\text { Investment Funds: An Institutional Analysis }\end{array}$ & David Ellerman & March 1998 \\
\hline $\begin{array}{l}\text { No. 166: Published in: Marketing Issues in } \\
\text { Transitional Economies, "Value Priorities } \\
\text { and Consumer Behavior in a Transitional } \\
\text { Economy: The Case of South Africa" ed. } \\
\text { Rajeev Batra. }\end{array}$ & $\begin{array}{l}\text { Steven M. Burgess and Jan-Benedict E.M. } \\
\text { Steenkamp }\end{array}$ & August 1998 \\
\hline $\begin{array}{l}\text { No. 164: Finance and Investment in } \\
\text { Transition: Czech Enterprises, 1993-1994 }\end{array}$ & Ronald Anderson and Chantal Kegels & September 1997 \\
\hline $\begin{array}{l}\text { No. 163: European Union Trade and } \\
\text { Investment Flows U-Shaping Industrial } \\
\text { Output in Central and Eastern Europe: } \\
\text { Theory and Evidence }\end{array}$ & Alexander Repkine and Patrick P. Walsh & April 1998 \\
\hline $\begin{array}{l}\text { No. 162: Skill Acquisition and Private Firm } \\
\text { Creation in Transition Economies }\end{array}$ & Zuzana Brixiova and Wenli $\mathrm{Li}$ & October 1999 \\
\hline No. 161: Corruption in Transition & Susanto Basu and David D. Li & May 1998 \\
\hline $\begin{array}{l}\text { No. 160a: Tenures that Shook the World: } \\
\text { Worker Turnover in Russia, Poland and } \\
\text { Britain }\end{array}$ & $\begin{array}{l}\text { Hartmut Lehmann and Jonathan } \\
\text { Wadsworth }\end{array}$ & November 1999 \\
\hline $\begin{array}{l}\text { No. 160: Tenures that Shook the World: } \\
\text { Worker Turnover in the Russian Federation } \\
\text { and Poland }\end{array}$ & $\begin{array}{l}\text { Hartmut Lehmann and Jonathan } \\
\text { Wadsworth }\end{array}$ & June 1998 \\
\hline $\begin{array}{l}\text { No. 159: Does Market Structure Matter? New } \\
\text { Evidence from Russia }\end{array}$ & Annette N. Brown and J. David Brown & June 1998 \\
\hline $\begin{array}{l}\text { No. 158: Structural Adjustment and Regional } \\
\text { Long Term Unemployment in Poland }\end{array}$ & Hartmut Lehmann and Patrick $P$. Walsh & June 1997 \\
\hline $\begin{array}{l}\text { No. 157: Baby Boom or Bust? Changing } \\
\text { Fertility in Post-Communist Czech Republic } \\
\text { and Slovakia }\end{array}$ & Robert S. Chase & April 1998 \\
\hline
\end{tabular}

Publications denoted by an asterisk are not available on the Kresge Library webpage (http://www.wdi.bus.umich.edu) 


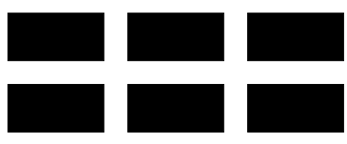

THE WILLIAM DAVIDSON INSTITUTE

AT THE UNIVERSITY OF MICHIGAN BUSINESSSCHOOL

\begin{tabular}{|c|c|c|}
\hline $\begin{array}{l}\text { No. } 156 \text { Published in: Leadership and } \\
\text { Organization Development Journal, } \\
\text { "Leading Radical Change in Transition } \\
\text { Economies." Vol. 19, No. 6, 1998, pp. 309- } \\
324 .\end{array}$ & Karen L. Newman & June 1998 \\
\hline $\begin{array}{l}\text { No. } 155 \text { Published in: Oxford Review of } \\
\text { Economic Policy, "From Theory into } \\
\text { Practice? Restructuring and Dynamism in } \\
\text { Transition Economies.” Vol. 13, No. 2, } \\
\text { Summer 1997, pp. 77-105. } \\
\end{array}$ & Wendy Carlin and Michael Landesmann & June 1997 \\
\hline $\begin{array}{l}\text { No. 154: The Model and the Reality: } \\
\text { Assessment of Vietnamese SOE Reform- } \\
\text { Implementation at the Firm Level }\end{array}$ & $\begin{array}{l}\text { Edmund Malesky, Vu Thanh Hung, Vu Thi } \\
\text { Dieu Anh, and Nancy K. Napier }\end{array}$ & July 1998 \\
\hline $\begin{array}{l}\text { No. } 153 \text { Published in: Journal of } \\
\text { Comparative Economics, "Causes of the Soft } \\
\text { Budget Constraint: Evidence on Three } \\
\text { Explanations." Vol. 26, No. 1, March 1998, } \\
\text { pp. 104-116. }\end{array}$ & David D. Li and Minsong Liang & March 1998 \\
\hline $\begin{array}{l}\text { No. } 152 \text { Published in: Comparative Economic } \\
\text { Studies, "Enterprise Restructuring in Russia's } \\
\text { Transition Economy: Formal and Informal } \\
\text { Mechanisms." Vol. 40, No. 2, Summer 1998, } \\
\text { pp. 5-52. }\end{array}$ & Susan J. Linz and Gary Krueger & April 1998 \\
\hline $\begin{array}{l}\text { No. 151: Labor Productivity in Transition: A } \\
\text { Regional Analysis of Russian Industry }\end{array}$ & Susan J. Linz. & May 1998 \\
\hline $\begin{array}{l}\text { No. 150: Tax Avoidance and the Allocation of } \\
\text { Credit. Forthcoming in Financial Systems in } \\
\text { Transition: The Design of Financial Systems } \\
\text { in Central Europe eds. Anna Meyendorff and } \\
\text { Anjan Thakor. }\end{array}$ & Anna Meyendorff & June 1998 \\
\hline $\begin{array}{l}\text { No. 149: Commitment, Versatility and } \\
\text { Balance: Determinants of Work Time } \\
\text { Standards and Norms in a Multi-Country } \\
\text { Study of Software Engineers }\end{array}$ & Leslie Perlow and Ron Fortgang & April 1998 \\
\hline $\begin{array}{l}\text { No. 148: Changes in Poland's Transfer } \\
\text { Payments in the 1990s: the Fate of } \\
\text { Pensioners }\end{array}$ & Bozena Leven & June 1998 \\
\hline $\begin{array}{l}\text { No. 147: Environmental Protection and } \\
\text { Economic Development: The Case of the } \\
\text { Huaihe River Basin Cleanup Plan }\end{array}$ & $\begin{array}{l}\text { Robert Letovsky, Reze Ramazani, and } \\
\text { Debra Murphy }\end{array}$ & June 1998 \\
\hline $\begin{array}{l}\text { No. 146: Chief Executive Compensation } \\
\text { During Early Transition: Further Evidence } \\
\text { from Bulgaria }\end{array}$ & $\begin{array}{l}\text { Derek C. Jones, Takao Kato, and Jeffrey } \\
\text { Miller }\end{array}$ & June 1998 \\
\hline $\begin{array}{l}\text { No. } 145 \text { Published in: Economics of } \\
\text { Transition, “Women's Unemployment During } \\
\text { the Transition: Evidence from Czech and } \\
\text { Slovak Micro Data," Vol. 7, No. 1, May 1999, } \\
\text { pp. 47-78. }\end{array}$ & $\begin{array}{l}\text { John Ham, Jan Svejnar, and Katherine } \\
\text { Terrell }\end{array}$ & May 1998 \\
\hline No. 144: Investment and Wages in Slovenia & Janez Prasnikar & May 1998 \\
\hline $\begin{array}{l}\text { No. } 143 \text { Published in: Review of Financial } \\
\text { Studies, "Optimal Bankruptcy Laws Across } \\
\text { Different Economic Systems," 12(2), Summer }\end{array}$ & Elazar Berkovitch and Ronen Israel & March 1998 \\
\hline
\end{tabular}

Publications denoted by an asterisk are not available on the Kresge Library webpage (http://www.wdi.bus.umich.edu) 


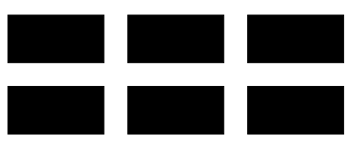

THE WILLIAM DAVIDSON INSTITUTE

AT THE UNIVERSITY OF MICHIGAN BUSINESSSCHOOL

\begin{tabular}{|c|c|c|}
\hline 1999, pgs. 347-77. & & \\
\hline $\begin{array}{l}\text { No. 142: Industrial Policy and Poverty in } \\
\text { Transition Economies: Two Steps Forward or } \\
\text { One Step Back? }\end{array}$ & Susan J. Linz & March 1998 \\
\hline $\begin{array}{l}\text { No. 141: Collective Ownership and } \\
\text { Privatization of China's Village Enterprises }\end{array}$ & Suwen Pan and Albert Park & April 1998 \\
\hline $\begin{array}{l}\text { No. 140: A Comparative Look at Labor } \\
\text { Mobility in the Czech Republic: Where have } \\
\text { all the Workers Gone? }\end{array}$ & Vit Sorm and Katherine Terrell & April 1999 \\
\hline $\begin{array}{l}\text { No. 139: The Failure of the Government-Led } \\
\text { Program of Corporate Reorganization in } \\
\text { Romania }\end{array}$ & Simeon Djankov and Kosali Ilayperuma & September 1997 \\
\hline $\begin{array}{l}\text { No. 138: Ownership and Employment in } \\
\text { Russian Industry: 1992-1995 }\end{array}$ & Susan J. Linz & March 1998 \\
\hline $\begin{array}{l}\text { No. } 137 \text { Published in: Journal of Political } \\
\text { Economy, "Reform Without Losers: An } \\
\text { Interpretation of China's Dual-Track } \\
\text { Approach to Transition," Feb. 2000; Vol. 108, } \\
\text { Iss.1; pg. } 120\end{array}$ & $\begin{array}{l}\text { Lawrence J. Lau, Yingyi Qian, and Gerard } \\
\text { Roland }\end{array}$ & November 1997 \\
\hline $\begin{array}{l}\text { No. } 136 \text { Published in: European Economic } \\
\text { Review, "The Political Economy of Mass } \\
\text { Privatization and the Risk of Expropriation," } \\
44(2), \text { February 2000, pgs. } 393-421\end{array}$ & Klaus M. Schmidt & March 1998 \\
\hline $\begin{array}{l}\text { No. 135: Radical Organizational Change: The } \\
\text { Role of Starting Conditions, Competition, and } \\
\text { Leaders }\end{array}$ & Karen L. Newman & January 1998 \\
\hline $\begin{array}{l}\text { No. 134: To Restructure or Not to } \\
\text { Restructure: Informal Activities and } \\
\text { Enterprise Behavior in Transition }\end{array}$ & Clifford Gaddy and Barry W. Ickes & May 1998 \\
\hline $\begin{array}{l}\text { No. 133: Management 101: Behavior of Firms } \\
\text { in Transition Economies }\end{array}$ & Josef C. Brada & March 1998 \\
\hline $\begin{array}{l}\text { No. } 132 \text { Published in: Quarterly Journal of } \\
\text { Economics, "Interfirm Relationships and } \\
\text { Informal Credit in Vietnam," 114(4), Nov. } \\
\text { 1999, pgs. 1285-1320 }\end{array}$ & John McMillan and Christopher Woodruff & February 1998 \\
\hline $\begin{array}{l}\text { No. } 131 \text { Published in: Comparative Economic } \\
\text { Studies, “Will Restructuring Hungarian } \\
\text { Companies Innovate? An Investigation Based } \\
\text { on Joseph Berliner's Analysis of Innovation in } \\
\text { Soviet Industry." Vol. 40, No. 2, Summer } \\
\text { 1998, pp. 53-74. }\end{array}$ & John B. Bonin and Istvan Abel & March 1998 \\
\hline $\begin{array}{l}\text { No. 130: Published in The American } \\
\text { Economic Review, "Changing Incentives of } \\
\text { the Chinese Bureaucracy." May, 1998. }\end{array}$ & David D. Li & January 1998 \\
\hline $\begin{array}{l}\text { No. 129: Restructuring Investment in } \\
\text { Transition: A Model of the Enterprise } \\
\text { Decision }\end{array}$ & Richard E. Ericson & Janиагу 1998 \\
\hline $\begin{array}{l}\text { No. } 128 \text { Published in: Comparative Economic } \\
\text { Studies, “Job Rights in Russian Firms: } \\
\text { Endangered or Extinct Institutions?" Vol. 40, } \\
\text { No. 4, Winter 1998, pp. 1-32. }\end{array}$ & Susan J. Linz & January 1998 \\
\hline No. 127: Accounting for Growth in Post- & Daniel Berkowitz and David N. DeJong & January 1998 \\
\hline
\end{tabular}

Publications denoted by an asterisk are not available on the Kresge Library webpage (http://www.wdi.bus.umich.edu) 


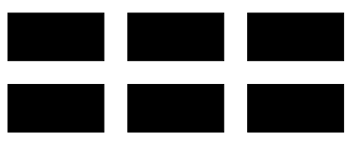

THE WILLIAM DAVIDSON INSTITUTE

AT THE UNIVERSITY OF MICHIGAN BUSINESSSCHOOL

\begin{tabular}{|c|c|c|}
\hline Soviet Russia & & \\
\hline $\begin{array}{l}\text { No. } 126 \text { Published in: Economics of } \\
\text { Transition, “From Federalism, Chinese Style, } \\
\text { to Privatization Chinese Style," } 7(1), 1999, \\
\text { pgs. } 103-31\end{array}$ & $\begin{array}{l}\text { Yuanzheng Cao, Yingyi Qian, and Barry R. } \\
\text { Weingast }\end{array}$ & December 1997 \\
\hline $\begin{array}{l}\text { No. 125: Market Discipline in Conglomerate } \\
\text { Banks: Is an Internal Allocation of Cost of } \\
\text { Capital Necessary as Incentive Device? } \\
\text { Forthcoming in Financial Systems in } \\
\text { Transition: The Design of Financial Systems } \\
\text { in Central Europe eds. Anna Meyendorff and } \\
\text { Anjan Thakor. }\end{array}$ & Arnoud W. A. Boot and Anjolein Schmeits & November 1997 \\
\hline $\begin{array}{l}\text { No. 124: Financial Discipline in the } \\
\text { Enterprise Sector in Transition Countries: } \\
\text { How Does China Compare? }\end{array}$ & Shumei Gao and Mark E. Schaffer & February 1998 \\
\hline $\begin{array}{l}\text { No. 123: Considerations of an Emerging } \\
\text { Marketplace: Managers' Perceptions in the } \\
\text { Southern African Economic Community }\end{array}$ & Brent Chrite and David Hudson & February 1998 \\
\hline $\begin{array}{l}\text { No. 122: A Model of the Informal Economy in } \\
\text { Transition Economies }\end{array}$ & $\begin{array}{l}\text { Simon Commander and Andrei } \\
\text { Tolstopiatenko }\end{array}$ & November 1997 \\
\hline $\begin{array}{l}\text { No. 121: Local Labour Market Dynamics in } \\
\text { the Czech and Slovak Republics }\end{array}$ & Peter Huber and Andreas Worgotter & November 1997 \\
\hline $\begin{array}{l}\text { No. 121: Local Labour Market Dynamics in } \\
\text { the Czech and Slovak Republics }\end{array}$ & Peter Huber and Andreas Worgotter & November 1997 \\
\hline $\begin{array}{l}\text { No. 119: Institutional Upheaval and Company } \\
\text { Transformation in Emerging Market } \\
\text { Economies }\end{array}$ & Karen L. Newman & March 1998 \\
\hline $\begin{array}{l}\text { No. 118: Industrial Decline and Labor } \\
\text { Reallocation in Romania }\end{array}$ & John S. Earle & October 1997 \\
\hline $\begin{array}{l}\text { No. 117: Notes for an Essay on the Soft } \\
\text { Budget Constraint }\end{array}$ & Lorand Ambrus-Lakatos & January 1997 \\
\hline $\begin{array}{l}\text { No. 116: Labor Demand During Transition in } \\
\text { Hungary }\end{array}$ & Gabor Korosi & October 1997 \\
\hline $\begin{array}{l}\text { No. 115: Enterprise Performance and } \\
\text { Managers' Profiles }\end{array}$ & Simeon Djankov and Stijn Claessens & December 1997 \\
\hline $\begin{array}{l}\text { No. } 114 b \text { Employment and Wages in } \\
\text { Enterprises under Communism and in } \\
\text { Transition: Evidence From Central Europe } \\
\text { and Russia }\end{array}$ & Swati Basu, Saul Estrin, and Jan Svejnar & April 2000 \\
\hline $\begin{array}{l}\text { No. 114: Employment and Wage Behavior of } \\
\text { Enterprises in Transitional Economies }\end{array}$ & Swati Basu, Saul Estrin, and Jan Svejnar & October 1997 \\
\hline $\begin{array}{l}\text { No. 113: Preliminary Evidence on Active } \\
\text { Labor Programs' Impact in Hungary and } \\
\text { Poland }\end{array}$ & Christopher J. O’Leary & October 1997 \\
\hline $\begin{array}{l}\text { No. 111: Unemployment Benefits and } \\
\text { Incentives in Hungary: New Evidence }\end{array}$ & Joachim Wolff & October 1997 \\
\hline $\begin{array}{l}\text { No. 110: Published in: Empirical Economics, } \\
\text { "Long-Term Unemployment, Unemployment } \\
\text { Benefits and Social Assistance: The Polish } \\
\text { Experience" Empirical-Economics; 23(1-2), } \\
\text { 1998, pages 55-85. }\end{array}$ & Marek Gora and Christoph M. Schmidt & April 1997 \\
\hline No. 109 Published in: Industrial and Labor & Robert S. Chase & October 1997 \\
\hline
\end{tabular}

Publications denoted by an asterisk are not available on the Kresge Library webpage

(http://www.wdi.bus.umich.edu) 


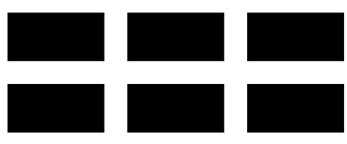

THE WILLIAM DAVIDSON INSTITUTE

AT THE UNIVERSITY OF MICHIGAN BUSINESSSCHOOL

\begin{tabular}{|c|c|c|}
\hline $\begin{array}{l}\text { Relations Review, "Markets for Communist } \\
\text { Human Capital: Returns to Education and } \\
\text { Experience in Post-Communist Czech } \\
\text { Republic and Slovakia." Vol. 51, No. 3, April } \\
\text { 1998, pp. 401-423. }\end{array}$ & & \\
\hline $\begin{array}{l}\text { No. 107: The Worker-Firm Matching in the } \\
\text { Transition: (Why) Are the Czechs More } \\
\text { Successful Than Others? }\end{array}$ & $\begin{array}{l}\text { Daniel Münich, Jan Svejnar, and } \\
\text { Katherine Terrell }\end{array}$ & October 1997 \\
\hline $\begin{array}{l}\text { No. } 106 \text { Published in: Journal of } \\
\text { Comparative Economics, “Job Creation, Job } \\
\text { Destruction and Growth of Newly Established, } \\
\text { Privatized and State-Owned Enterprises in } \\
\text { Transition Economies: Survey Evidence from } \\
\text { Bulgaria, Hungary, and Romania,” Vol. 26, } \\
\text { No.3, September 1998, pp. 429-445. }\end{array}$ & Valentijn Bilsen and Jozef Konings & September 1998 \\
\hline $\begin{array}{l}\text { No. 105: Getting Behind the East-West } \\
\text { [German] Wage Differential: Theory and } \\
\text { Evidence }\end{array}$ & Michael Burda and Christoph Schmidt & May 1997 \\
\hline $\begin{array}{l}\text { No. 104: The Birth of the "Wage Curve" in } \\
\text { Hungary, 1989-95 }\end{array}$ & Gabor Kertesi and Janos Kollo & October 1997 \\
\hline $\begin{array}{l}\text { No. 103: Published in: Journal of } \\
\text { Comparative Economics, "Grime and } \\
\text { Punishment: Job Insecurity and Wage Arrears } \\
\text { in the Russian Federation" 27, 595-617 } \\
\text { (1999). }\end{array}$ & $\begin{array}{l}\text { Hartmut Lehmann, Jonathan Wadsworth, } \\
\text { and Alessandro Acquisti }\end{array}$ & October 1997 \\
\hline No. 102: Social Networks in Transition & $\begin{array}{l}\text { Lorena Barberia, Simon Johnson, and } \\
\text { Daniel Kaufmann }\end{array}$ & October 1997 \\
\hline $\begin{array}{l}\text { No. 101: Depreciation and Russian Corporate } \\
\text { Finance: A Pragmatic Approach to Surviving } \\
\text { the Transition }\end{array}$ & Susan J. Linz & November 1997 \\
\hline No. 100: Romanian Financial System Reform & Anna Meyendorff and Anjan V. Thakor & November 1997 \\
\hline $\begin{array}{l}\text { No. 99: Proceedings of the Conference on } \\
\text { Strategic Alliances in Transitional Economies, } \\
\text { held May 20, } 1997 \text { at the Davidson Institute }\end{array}$ & Edited by Cynthia Koch & May 1997 \\
\hline $\begin{array}{l}\text { No. 98: Institutions, Strain and the } \\
\text { Underground Economy }\end{array}$ & Daniel Daianu and Lucian Albu & November 1997 \\
\hline $\begin{array}{l}\text { No. 97: Structure and Strain in Explaining } \\
\text { Inter-Enterprise Arrears } \\
\text { No. 96: Resource Misallocation and Strain: } \\
\text { Explaining Shocks in Post-Command } \\
\text { Economies }\end{array}$ & $\begin{array}{l}\text { Daniel Daianu } \\
\text { Daniel Daianu }\end{array}$ & $\begin{array}{l}\text { November } 1997 \\
\text { November } 1997\end{array}$ \\
\hline $\begin{array}{l}\text { No. 95: Published in: Finance-a-Uver, } \\
\text { "Czech Money Market: Emerging Links } \\
\text { Among Interest Rates." 48(2) } 1998 \text { pp. 99- } \\
\text { 109. }\end{array}$ & Jan Hanousek and Evzen Kocenda & November 1997 \\
\hline $\begin{array}{l}\text { No. 94: Pre-Reform Industry and the } \\
\text { State Monopsony in China }\end{array}$ & Xiao-Yuan Dong and Louis Putterman & October 1997 \\
\hline $\begin{array}{l}\text { No. 93: China's State-Owned Enterprises } \\
\text { In the First Reform Decade: } \\
\text { An Analysis of a Declining Monopsony }\end{array}$ & Xiao-Yuan Dong and Louis Putterman & October 1997 \\
\hline $\begin{array}{l}\text { No. 92: Expatriate Management in the Czech } \\
\text { Republic }\end{array}$ & Richard B. Peterson & September 1997 \\
\hline
\end{tabular}

Publications denoted by an asterisk are not available on the Kresge Library webpage (http://www.wdi.bus.umich.edu) 


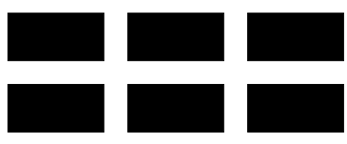

THE WILliam DAVIDSON InSTITUTE

AT THE UNIVERSITY OF MICHIGAN BUSINESSSCHOOL

\begin{tabular}{|c|c|c|}
\hline $\begin{array}{l}\text { No. 91: China and the Idea of Economic } \\
\text { Reform }\end{array}$ & Thomas G. Rawski & April 1997 \\
\hline $\begin{array}{l}\text { No. } 90 \text { Published in: China Economic } \\
\text { Review, “China's State Enterprise Reform: An } \\
\text { Overseas Perspective.” Vol. 8, Spring 1997, } \\
\text { pp. 89-98. }\end{array}$ & Thomas G. Rawski & July 1997 \\
\hline $\begin{array}{l}\text { No. 89: The Economic Determinants of } \\
\text { Internal Migration Flows in Russia During } \\
\text { Transition }\end{array}$ & Annette N. Brown & July 1997 \\
\hline $\begin{array}{l}\text { No. 88: Gender Wage Gaps in China's Labor } \\
\text { Market: Size, Structure, Trends }\end{array}$ & $\begin{array}{l}\text { Margaret Maurer-Fazio, Thomas G. } \\
\text { Rawski, and Wei Zhang }\end{array}$ & July 1997 \\
\hline $\begin{array}{l}\text { No. 87: Privatisation in Central and Eastern } \\
\text { Europe }\end{array}$ & Saul Estrin & June 1997 \\
\hline $\begin{array}{l}\text { No. 86: Published in : Economics of } \\
\text { Transition, "The Effect of Privatization on } \\
\text { Wealth Distribution in Russia." v. 7, no. 2, } \\
\text { 1999, pp. } 449-65\end{array}$ & Michael Alexeev & February 1998 \\
\hline $\begin{array}{l}\text { No. 85: Was Privatization in Eastern Germany } \\
\text { a Special Case? Some Lessons from the } \\
\text { Treuhand }\end{array}$ & Uwe Siegmund & September 1997 \\
\hline No. 84: Start-ups and Transition & Daniel M. Berkowitz and David J. Cooper & September 1997 \\
\hline $\begin{array}{l}\text { No. 83: Which Enterprises (Believe They) } \\
\text { Have Soft Budgets after Mass Privatization? } \\
\text { Evidence from Mongolia }\end{array}$ & $\begin{array}{l}\text { James Anderson, Georges Korsun, and } \\
\text { Peter Murrell }\end{array}$ & October 1997 \\
\hline $\begin{array}{l}\text { No. 82: Published in: European Economic } \\
\text { Review, "Unemployment Dynamics and the } \\
\text { Restructuring of the Slovak Unemployment } \\
\text { Benefit System." April, 1997. }\end{array}$ & Martina Lubyova and Jan C. van Ours & June 1997 \\
\hline $\begin{array}{l}\text { No. 81: Determinants of Unemployment } \\
\text { Duration in Russia }\end{array}$ & Mark C. Foley & August 1997 \\
\hline $\begin{array}{l}\text { No. 80: The Many Faces of Information } \\
\text { Disclosure }\end{array}$ & Arnoud W.A. Boot and Anjan V. Thakor & October 1997 \\
\hline $\begin{array}{l}\text { No. 79: Published in: Journal of Finance, } \\
\text { "Foreign Speculators and Emerging Equity } \\
\text { Markets."v.22, iss. 2, 2000, pp. 565-613 }\end{array}$ & Geert Bekaert and Campbell R. Harvey & August 1997 \\
\hline $\begin{array}{l}\text { No. 78: The Relationship Between Economic } \\
\text { Factors and Equity Markets in Central Europe }\end{array}$ & Jan Hanousek and Randall K. Filer & June 1997 \\
\hline $\begin{array}{l}\text { No. } 77 \text { Published in: Economics of } \\
\text { Transition, “A Gini Decomposition Analysis } \\
\text { of Inequality in the Czech and Slovak } \\
\text { Republics During the Transition," Vol. 6, } \\
\text { No.1, May 1998, pp. 23-46. }\end{array}$ & Thesia I. Garner and Katherine Terrell & May 1998 \\
\hline $\begin{array}{l}\text { No. 76: China's Emerging Market for } \\
\text { Property Rights: Theoretical and Empirical } \\
\text { Perspectives }\end{array}$ & Gary H. Jefferson and Thomas G. Rawski & June 1997 \\
\hline $\begin{array}{l}\text { No. } 75 b: \text { Test of Permanent Income } \\
\text { Hypothesis on Czech Voucher Privatization }\end{array}$ & Jan Hanousek and Zdenek Tima & October 1997 \\
\hline $\begin{array}{l}\text { No. 74: Determinants of Performance of } \\
\text { Manufacturing Firms in Seven European } \\
\text { Transition Economies }\end{array}$ & $\begin{array}{l}\text { Stijn Claessens, Simeon Djankov, and } \\
\text { Gerhard Pohl }\end{array}$ & February 1997 \\
\hline $\begin{array}{l}\text { No. } 73 \text { Published in: Economics of } \\
\text { Transition, "The Restructuring of Large }\end{array}$ & Simeon Djankov and Gerhard Pohl & May 1998 \\
\hline
\end{tabular}

Publications denoted by an asterisk are not available on the Kresge Library webpage

(http://www.wdi.bus.umich.edu) 


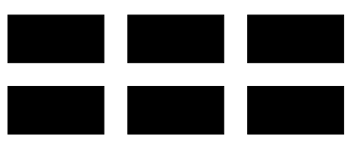

THE WILLIAM DAVIDSON INSTITUTE

AT THE UNIVERSITY OF MICHIGAN BUSINESSSCHOOL

\begin{tabular}{|c|c|c|}
\hline $\begin{array}{l}\text { Firms in Slovak Republic.” Vol. 6, No. 1, May } \\
\text { 1998, pp. 67-85 }\end{array}$ & & \\
\hline $\begin{array}{l}\text { No. 72: Law, Relationships, and Private } \\
\text { Enforcement: Transactional Strategies of } \\
\text { Russian Enterprises }\end{array}$ & $\begin{array}{l}\text { Kathryn Hendley, Peter Murrell, and } \\
\text { Randi Ryterman }\end{array}$ & November 1998 \\
\hline $\begin{array}{l}\text { No. 71: Giving Credit Where Credit Is Due: } \\
\text { The Changing Role of Rural Financial } \\
\text { Institutions in China }\end{array}$ & Albert Park, Loren Brandt, and John Giles & March 1997 \\
\hline $\begin{array}{l}\text { No. 70: Privatization Versus Competition: } \\
\text { Changing Enterprise Behavior in Russia }\end{array}$ & John S. Earle and Saul Estrin & Spring 1997 \\
\hline $\begin{array}{l}\text { No. 69: Russian Managers under Storm: } \\
\text { Explicit Reality and Implicit Leadership } \\
\text { Theories (A Pilot Exploration) }\end{array}$ & Igor Gurkov & October 1998 \\
\hline $\begin{array}{l}\text { No. 68: The Political Economy of Central- } \\
\text { Local Relations in China: Inflation and } \\
\text { Investment Controls During the Reform Era }\end{array}$ & Yasheng Huang & Spring 1997 \\
\hline $\begin{array}{l}\text { No. 67: Between Two Coordination Failures: } \\
\text { Automotive Industrial Policy in China with a } \\
\text { Comparison to Korea }\end{array}$ & Yasheng Huang & Spring 1997 \\
\hline $\begin{array}{l}\text { No. } 66 \text { Published in: Post-Soviet Geography } \\
\text { and Economics, "Red Executives in Russia's } \\
\text { Transition Economy." Vol. 27, No. 10, } \\
\text { November 1996, pp. 633-651. }\end{array}$ & Susan J. Linz & January 1997 \\
\hline $\begin{array}{l}\text { No. } 65 \text { Published in: Industrial and } \\
\text { Corporate Change, "On the Sequencing of } \\
\text { Privatization in Transition Economies." Vol. } \\
7, \text { No. 1, 1998. }\end{array}$ & Gautam Ahuja and Sumit K. Majumdar & April 1997 \\
\hline $\begin{array}{l}\text { No. 64: Published in: Journal of Law and } \\
\text { Economics, "Foreign Ownership and } \\
\text { Profitability: Property Rights, Control and the } \\
\text { Performance of Firms in Indian Industry" } \\
\text { 42(1), April 1999, pp. 209-38. }\end{array}$ & $\begin{array}{l}\text { Pradeep K. Chhibber and Sumit K. } \\
\text { Majumdar }\end{array}$ & April 1997 \\
\hline $\begin{array}{l}\text { No. 63: How Taxing Is Corruption on } \\
\text { International Investors? }\end{array}$ & Shang-Jin Wei & February 1997 \\
\hline $\begin{array}{l}\text { No. 62: What Can We Learn from the } \\
\text { Experience of Transitional Economies with } \\
\text { Labour Market Policies? } \\
\text { No. 61: Published in: Accounting } \\
\text { Organizations and Society, "Economic } \\
\text { Transition, Strategy and the Evolution of } \\
\text { Management Accounting Practices: The Case } \\
\text { of India" 24(5,6), Jul/Aug 1999, pp. 379-412. }\end{array}$ & $\begin{array}{l}\text { Tito Boeri } \\
\text { Shannon W. Anderson and William N. } \\
\text { Lanen }\end{array}$ & 1997 \\
\hline $\begin{array}{l}\text { No. 60a: Enterprise Investment During the } \\
\text { Transition: Evidence from Czech Panel Data }\end{array}$ & Lubomír Lizal and Jan Svejnar & December 1997 \\
\hline $\begin{array}{l}\text { No. 59: Published in: Journal of Law, } \\
\text { Economics, and Organization, "Institutional } \\
\text { Environment, Community Government, and } \\
\text { Corporate Governance: Understanding } \\
\text { China's Township-Village Enterprises." } \\
\text { 14(1), April 1998, pages 1-23 }\end{array}$ & Jiahua Che and Yingyi Qian & April 1997 \\
\hline $\begin{array}{l}\text { No. 58: From the Grabbing Hand to the } \\
\text { Helping Hand }\end{array}$ & Jiahua Che & June 2000 \\
\hline
\end{tabular}

Publications denoted by an asterisk are not available on the Kresge Library webpage (http://www.wdi.bus.umich.edu) 


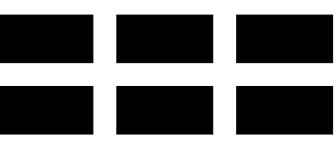

THE WILLIAM DAVIDSON INSTITUTE

AT THE UNIVERSITY OF MICHIGAN BUSINESSSCHOOL

\begin{tabular}{|c|c|c|}
\hline $\begin{array}{l}\text { No. 57: Published in: Brookings Papers on } \\
\text { Economic Activity, “The Unofficial Economy } \\
\text { in Transition.” 1: 1998. }\end{array}$ & $\begin{array}{l}\text { Simon Johnson, Daniel Kaufmann, and } \\
\text { Andrei Schleifer }\end{array}$ & June 1997 \\
\hline $\begin{array}{l}\text { No. 56: Taxes and Government Incentives: } \\
\text { Eastern Europe vs. China }\end{array}$ & Roger H. Gordon and David D. Li & April 1997 \\
\hline No. 55: Corruption and Reform & Susanto Basu and David Li & June 1996 \\
\hline $\begin{array}{l}\text { No. 54: Decentralization and the } \\
\text { Macroeconomic Consequences of } \\
\text { Commitment to State-Owned Firms }\end{array}$ & Loren Brandt and Xiaodong Zhu & June 1997 \\
\hline $\begin{array}{l}\text { No. 53: Published in: The International } \\
\text { Journal of Industrial Organization, } \\
\text { "Competitive Shocks and Industrial Structure: } \\
\text { The Case of Polish Manufacturing." August, } \\
\text { 1999. . }\end{array}$ & Pankaj Ghemawat and Robert E. Kennedy & May 1997 \\
\hline $\begin{array}{l}\text { No. 52: Published in: The Quarterly Journal } \\
\text { of Economics, "Insecure Property Rights and } \\
\text { Government Ownership of Firms." May, } \\
\text { 1998. }\end{array}$ & Jiahua Che and Yingyi Qian & May 1997 \\
\hline $\begin{array}{l}\text { No. 51: Incentives, Scale Economies, and } \\
\text { Organizational Form }\end{array}$ & $\begin{array}{l}\text { Eric Maskin, Yingyi Qian, and Chenggang } \\
X u\end{array}$ & May 1997 \\
\hline $\begin{array}{l}\text { No. 50: Published in: Post-Soviet-Affairs, } \\
\text { "End of the Tunnel? The Effects of Financial } \\
\text { Stabilization in Russia" April-June 1997, } \\
\text { pages 105-33 }\end{array}$ & $\begin{array}{l}\text { Barry W. Ickes, Peter Murrell, and Randi } \\
\text { Ryterman }\end{array}$ & March 1997 \\
\hline $\begin{array}{l}\text { No. 49: The Evolution of Bank Credit Quality } \\
\text { in Transition: Theory and Evidence from } \\
\text { Romania }\end{array}$ & Enrico C. Perotti and Octavian Carare & October 1996 \\
\hline $\begin{array}{l}\text { No. 48: Where Do the Leaders Trade? } \\
\text { Information Revelation and Interactions } \\
\text { Between the Segments of Czech Capital } \\
\text { Markets }\end{array}$ & Jan Hanousek and Libor Nemecek & May 1997 \\
\hline $\begin{array}{l}\text { No. 47: Firms' Heterogeneity in Transition: } \\
\text { Evidence from a Polish Panel Data Set }\end{array}$ & Irena Grosfeld and Jean-François Nivet & May 1997 \\
\hline $\begin{array}{l}\text { No. 46: Strategic Creditor Passivity, } \\
\text { Regulation, and Bank Bailouts }\end{array}$ & Janet Mitchell & May 1997 \\
\hline $\begin{array}{l}\text { No. } 45 \text { a: Decentralization in Transition } \\
\text { Economies: A Tragedy of the Commons? }\end{array}$ & Daniel M. Berkowitz and Wei Li & September 1997 \\
\hline $\begin{array}{l}\text { No. 44a: The Information Content of Stock } \\
\text { Markets: Why do Emerging Markets have } \\
\text { Synchronous Stock Price Movements? } \\
\text { (forthcoming in the Journal of Financial } \\
\text { Economics). } \\
\text { No. 43: Agency in Project Screening and } \\
\text { Termination Decisions: Why Is Good Money } \\
\text { Thrown After Bad? }\end{array}$ & $\begin{array}{l}\text { Randall Morck, Bernard Yeung, and } \\
\text { Wayne Yu } \\
\text { Chong-en Bai and Yijiang Wang }\end{array}$ & May 1997 \\
\hline $\begin{array}{l}\text { No. 42: Published in: Economics of } \\
\text { Transition, "Channels of Redistribution: } \\
\text { Inequality and Poverty in the Russian } \\
\text { Transition." Vol. } 7 \text { (2) } 1999 . \\
\end{array}$ & $\begin{array}{l}\text { Simon Commander, Andrei Tolstopiatenko, } \\
\text { and Ruslan Yemtsov }\end{array}$ & May 1997 \\
\hline $\begin{array}{l}\text { No. 41: Published in: Economics of } \\
\text { Transition, "Labour Market Characteristics } \\
\text { and Profitability: Econometric Analysis of }\end{array}$ & László Halpern and Gabor Korosi & May 1997 \\
\hline
\end{tabular}

Publications denoted by an asterisk are not available on the Kresge Library webpage (http://www.wdi.bus.umich.edu) 


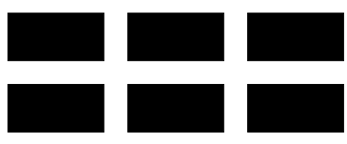

THE WILLIAM DAVIDSON INSTITUTE

AT THE UNIVERSITY OF MICHIGAN BUSINESSSCHOOL

\begin{tabular}{|c|c|c|}
\hline $\begin{array}{l}\text { Hungarian Exporting Firms, 1986-1995" } \\
6(1), \text { May 1998, pages 145-62 }\end{array}$ & & \\
\hline $\begin{array}{l}\text { No. 40: Published in: the Harvard Law } \\
\text { Review, "The Tragedy of the Anticommons: } \\
\text { Property in the Transition from Marx to } \\
\text { Markets." January 1998. }\end{array}$ & Michael Heller & February 1997 \\
\hline $\begin{array}{l}\text { No. 39: Privatization and Managerial } \\
\text { Efficiency }\end{array}$ & Olivier Debande and Guido Friebel & May 1997 \\
\hline $\begin{array}{l}\text { No. } 38 \text { Published in: The Quarterly Journal } \\
\text { of Economics, "Disorganization." Vol. 112, } \\
\text { No. 4, November 1997, pp. 1091-1126. }\end{array}$ & Olivier Blanchard and Michael Kremer & January 1997 \\
\hline $\begin{array}{l}\text { No. 37: Published in: Economics of } \\
\text { Transition, "Transition and the Output Fall." } \\
\text { 7(1), 1999, pages 1-28. }\end{array}$ & Gérard Roland and Thierry Verdier & March 1997 \\
\hline $\begin{array}{l}\text { No. 36: Restructuring an Industry During } \\
\text { Transition: A Two-Period Model }\end{array}$ & Richard Ericson & September 1996 \\
\hline $\begin{array}{l}\text { No. 34: The East-West Joint Venture: BC } \\
\text { Torsion Case Study }\end{array}$ & Sonia Ferencikova and Vern Terpstra & December 1998 \\
\hline $\begin{array}{l}\text { No. } 33 \text { Published in: Journal of Comparative } \\
\text { Economics, "Quantifying Price Liberalization } \\
\text { in Russia." Vol. 26, No. 4, December 1998, } \\
\text { pp. } 735-737 .\end{array}$ & $\begin{array}{l}\text { Daniel Berkowitz, David DeJong, and } \\
\text { Steven Husted }\end{array}$ & December 1998 \\
\hline $\begin{array}{l}\text { No. 32: What Can North Korea Learn from } \\
\text { China's Market Reforms? }\end{array}$ & John McMillan & September 1996 \\
\hline $\begin{array}{l}\text { No. 31: Published in: China-Economic- } \\
\text { Review, "Towards a Model of China as a } \\
\text { Partially Reformed Developing Economy } \\
\text { Under a Semifederalist Government.", 9(1), } \\
\text { Spring 1998, pages 1-23. }\end{array}$ & Yijiang Wang and Chun Chang & March 1997 \\
\hline $\begin{array}{l}\text { No. 30: Convergence in Output in Transition } \\
\text { Economies: Central and Eastern Europe, } \\
\text { 1970-1995 }\end{array}$ & Saul Estrin and Giovanni Urga & February 1997 \\
\hline $\begin{array}{l}\text { No. 29: Published in: Economics of } \\
\text { Transition, "Altered Band and Exchange } \\
\text { Volatility." Volume 6, no. 1, 1998, 173-181. }\end{array}$ & Evzen Kocenda & March 1997 \\
\hline $\begin{array}{l}\text { No. 28: Published in: Quarterly Journal of } \\
\text { Economics, "Public Versus Private } \\
\text { Ownership of Firms: Evidence from Rural } \\
\text { China." Volume 113, no. 3, August 1998, 773- } \\
\text { 808. }\end{array}$ & Hehui Jin and Yingyi Qian & January 1997 \\
\hline $\begin{array}{l}\text { No. 27: East-West Joint Ventures in a } \\
\text { Transitional Economy: The Case of Slovakia }\end{array}$ & Sonia Ferencikova & March 1997 \\
\hline $\begin{array}{l}\text { No. 26: Published in Economic Analysis } \\
\text { "Behavior of a Slovenian Firm in Transition" } \\
\text { Vol. 1, no. 1, 1998, 57-73. }\end{array}$ & Janez Prasnikar & February 1997 \\
\hline $\begin{array}{l}\text { No. 25: Cultural Encounters and Claims to } \\
\text { Expertise in Postcommunist Capitalism }\end{array}$ & Michael D. Kennedy & February 1997 \\
\hline $\begin{array}{l}\text { No. 24: ZVU a.s.: Investment Funds on the } \\
\text { Board of Directors of an Engineering Giant }\end{array}$ & Tory Wolff & August 1995 \\
\hline $\begin{array}{l}\text { No. 23: The Role of Investment Funds in the } \\
\text { Czech Republic (joint publication with Czech } \\
\text { Management Center) }\end{array}$ & Dusan Triska & June 1996 \\
\hline
\end{tabular}

Publications denoted by an asterisk are not available on the Kresge Library webpage (http://www.wdi.bus.umich.edu) 


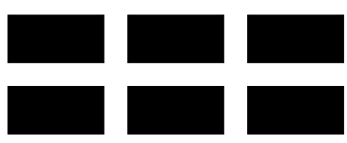

THE WILLIAM DAVIDSON INSTITUTE

AT THE UNIVERSITY OF MICHIGAN BUSINESSSCHOOL

\begin{tabular}{|c|c|c|}
\hline $\begin{array}{l}\text { No. 22: Czech Investment Fund Industry: } \\
\text { Development and Behaviour (joint publication } \\
\text { with Czech Management Center) }\end{array}$ & Richard Podpiera & May 1996 \\
\hline $\begin{array}{l}\text { No. 21: Restructuring of Czech Firms: An } \\
\text { Example of Gama, a.s. (joint publication with } \\
\text { Czech Management Center) }\end{array}$ & Antonin Bulin & June 1996 \\
\hline $\begin{array}{l}\text { No. 20: YSE Funds: A Story of Czech } \\
\text { Investment Funds (joint publication with } \\
\text { Czech Management Center) }\end{array}$ & Michal Otradovec & November 1995 \\
\hline $\begin{array}{l}\text { No. 19: První Investicni a.s., The First } \\
\text { Investment Corporation (joint publication } \\
\text { with Czech Management Center) }\end{array}$ & Jaroslav Jirasek & August 1995 \\
\hline $\begin{array}{l}\text { No. 18: PPF a.s., The First Private Investment } \\
\text { Fund (joint publication with Czech } \\
\text { Management Center) }\end{array}$ & Michal Otradovec & November 1995 \\
\hline $\begin{array}{l}\text { No. } 17 \text { Published in: Post-Soviet Geography } \\
\text { and Economics, "Russia's Managers in } \\
\text { Transition: Pilferers or Paladins?" Vol. } 37 \text {, } \\
\text { o.7 (September 1996), pp. 397-426. }\end{array}$ & Susan J. Linz and Gary Krueger & November 1996 \\
\hline $\begin{array}{l}\text { No. 16: Banks in Transition-Investment } \\
\text { Opportunities in Central Europe and Russia } \\
\text { Edited Transcript from } 31 \text { May } 1996 \\
\text { Conference in New York City }\end{array}$ & $\begin{array}{l}\text { With commentary and edited by Anna } \\
\text { Meyendorff }\end{array}$ & January 1997 \\
\hline $\begin{array}{l}\text { No. 15: Marketing in Transitional Economies: } \\
\text { Edited Transcript \& Papers from } 1 \text { April } 1996 \\
\text { Conference in Ann Arbor, Michigan }\end{array}$ & Compiled by The Davidson Institute & December 1996 \\
\hline $\begin{array}{l}\text { No. 14: Pensions in the Former Soviet Bloc: } \\
\text { Problems and Solutions. Published by } \\
\text { Council on Foreign Relations. "The Coming } \\
\text { Global Pension Crisis" New York, } 1997\end{array}$ & Jan Svejnar & November 1996 \\
\hline $\begin{array}{l}\text { No. 13: Enterprise Restructuring and } \\
\text { Performance in the Transition. Forthcoming } \\
\text { in Financial Systems in Transition: The } \\
\text { Design of Financial Systems in Central } \\
\text { Europe eds. Anna Meyendorff and Anjan } \\
\text { Thakor. }\end{array}$ & $\begin{array}{l}\text { Lubomir Lizal, Miroslav Singer, and Jan } \\
\text { Svejnar }\end{array}$ & December 1996 \\
\hline $\begin{array}{l}\text { No. } 12 \text { Published in: Journal of International } \\
\text { Marketing, "Executive Insights: Marketing } \\
\text { Issues and Challenges in Transitional } \\
\text { Economies." Vol. 5, No. 4, 1997, pp. 95-114. } \\
\text { Also published in: Marketing Issues in } \\
\text { Transitional Economies ed. Rajeev Batra. }\end{array}$ & Rajeev Batra & April 1997 \\
\hline $\begin{array}{l}\text { No. 11: Worker Trust and System } \\
\text { Vulnerability in the Transition from Socialism } \\
\text { to Capitalism }\end{array}$ & Andrew Schotter & August 1996 \\
\hline $\begin{array}{l}\text { No. } 10 \text { Published in: Comparative Economic } \\
\text { Studies, "Russian Firms in Transition: } \\
\text { Champions, Challengers, and Chaff." Vol. } \\
\text { 39, No.2, Summer 1997, pp. 1-36. }\end{array}$ & Susan J. Linz & July 1996 \\
\hline $\begin{array}{l}\text { No. 9: Corporate Debt Crisis and Bankruptcy } \\
\text { Law During the Transition: The Case of China }\end{array}$ & David D. Li and Shan Li & December 1995 \\
\hline No. 8 Published in: Journal of Comparative & David D. Li & June 1996 \\
\hline
\end{tabular}

Publications denoted by an asterisk are not available on the Kresge Library webpage (http://www.wdi.bus.umich.edu) 


\section{$\square \square$ \\ $\square$ \\ THE WILLIAM DAVIDSON INSTITUTE \\ AT THE UNIVERSITY OF MICHIGAN BUSINESSSCHOOL}

\begin{tabular}{|c|c|c|}
\hline $\begin{array}{l}\text { Economics, "A Theory of Ambiguous } \\
\text { Property Rights in Transition Economies: The } \\
\text { Case of the Chinese Non-State Sector." Vol. } \\
\text { 23, No. 1, August 1996, pp. 1-19. }\end{array}$ & & \\
\hline $\begin{array}{l}\text { No. 7: The Foreign Economic Contract Law of } \\
\text { China: Cases and Analysis }\end{array}$ & Dong-lai $\mathrm{Li}$ & June 1993 \\
\hline $\begin{array}{l}\text { No. 3: Bank Privatization in Hungary and the } \\
\text { Magyar Kulkereskedelmi Bank Transaction }\end{array}$ & Roger Kormendi and Karen Schnatterly & May 1996 \\
\hline $\begin{array}{l}\text { Replacing Nos. 1-2 \& 4-6: Journal of } \\
\text { Comparative Economics Symposium on } \\
\text { "Bank Privatization in Central Europe and } \\
\text { Russia." Vol. 25, No. 1, August } 1997 .\end{array}$ & $\begin{array}{l}\text { No. } 1 \text { "Bank Privatization in Transitional } \\
\text { Economies" by Roger Kormendi and } \\
\text { Edward Snyder. No. } 2 \text { "Transactional } \\
\text { Structures of Bank Privatizations in } \\
\text { Central Europe and Russia" by Anna } \\
\text { Meyendorff and Edward A. Snyder. No. } 4 \\
\text { "Bank Privatization in Poland: The Case } \\
\text { of Bank Slaski" by Jeffery Abarbaness and } \\
\text { John Bonin. No. } 5 \text { "Bank Privatization in } \\
\text { Post-Communist Russia: The Case of } \\
\text { Zhilsotsbank" by Jeffery Abarbanell and } \\
\text { Anna Meyendorff and No. } 6 \text { "'The Czech } \\
\text { Republic's Commercial Bank: Komercni } \\
\text { Banka" by Edward A. Snyder and Roger } \\
\text { C. Kormendi. }\end{array}$ & August 1997 \\
\hline
\end{tabular}

Publications denoted by an asterisk are not available on the Kresge Library webpage (http://www.wdi.bus.umich.edu) 